\title{
Paleoenvironmental and paleoclimatic records from permafrost deposits in the Arctic region of Northern Siberia
}

\author{
Lutz Schirrmeister $^{\mathrm{a}, *}$, Christine Siegert ${ }^{\mathrm{a}}$, Tatyana Kuznetsova ${ }^{\mathrm{b}}$, Svetlana Kuzmina ${ }^{\mathrm{c}}$, \\ Andrei Andreev ${ }^{\mathrm{a}}$, Frank Kienast ${ }^{\mathrm{a}}$, Hanno Meyer ${ }^{\mathrm{a}}$, Anatoly Bobrov ${ }^{\mathrm{d}}$ \\ ${ }^{a}$ Alfred Wegener Institute for Polar and Marine Research, Research Unit Potsdam, Telegrafenberg A43, D-14473 Potsdam, Germany \\ ${ }^{\mathrm{b}}$ Moscow State University, Faculty of Geology, 119899, Moscow, Russia \\ ${ }^{\mathrm{c}}$ Severtsov Institute of Ecology and Evolution, Russian Academy of Sciences, 33 Leninsky Prospect, 117071 Moscow, Russia \\ ${ }^{\mathrm{d}}$ Moscow State University, Faculty of Soil Sciences, 119899, Moscow, Russia
}

\begin{abstract}
Ice Complexes, extremely ice-rich permafrost deposits with large ice wedges, are widely distributed in the Arctic region of northeast Siberia. They present excellent archives for the reconstruction of Late Quaternary paleoenvironmental conditions in nonglaciated areas. In 1998, 1999, and 2000 Russian and German scientists worked together on the Bykovsky Peninsula southeast of the Lena Delta in order to investigate the Ice Complex and its associated sediments. Intensive cryolithological and sedimentological studies, Radiocarbon age determinations, paleobotanical studies, micropaleontological investigations, studies of mammal and insect fossils, and stable isotope analyses of ground ice were performed. Radiocarbon data have been obtained from the entire exposed sequence covering approximately the last 60,000 years. The results indicate that compared with modern time the investigated Ice Complex sequence was formed during two cooler and more arid stages of the Late Pleistocene with relatively uniform environmental conditions, separated by a stage with environmental variations and more intensive soil formation caused by climate amelioration. The Late Pleistocene environmental changes were not as strong as those occurring during the Pleistocene/Holocene transition where a sharp break is evident. (C) 2002 Elsevier Science Ltd and INQUA. All rights reserved.
\end{abstract}

\section{Introduction}

The Late Quaternary environmental history of Northern Siberia is still a much-debated subject. Some researchers have assumed that the Siberian Arctic as a whole was glaciated (Grosswald, 1998). Others have suggested that extremely cold and dry climates predominated, without large ice sheets (Velichko, 1993). Instead of glacial deposits, extremely ice-rich permafrost deposits in excess of $40 \mathrm{~m}$ thickness with large ice wedges, called Ice Complexes, are widely distributed in the lowlands of northern Yakutia and on the New Siberian Islands (Fig. 1). A great number of hypotheses exist about the genesis of these deposits. The lithogenetic conceptions include glacier-dammed basin sediments (Grosswald, 1998), alluvial genesis (Rozenbaum, 1981; Slagoda, 1991), slope deposits (Gravis, 1969), Arctic loess (Tomirdiaro et al., 1984; Tomirdiaro and Chernenky, 1987), and nival deposits (Kunitsky, 1989;

\footnotetext{
*Corresponding author.

E-mail address: 1schirrmeister@awi-postdam.de (L. Schirrmeister).
}

Galabala, 1997) as well as polygenetic origins (Sher et al., 1987). Ice Complexes are very important because numerous paleo-ecological, geochemical, sedimentological, and isotopic data are stored in this syngenetically formed permafrost. The cliff of the Bykovsky Peninsula at the southern Laptev Sea (Fig. 2) has been known for more than 200 years (Adams, 1807) and as a key location for Late Quaternary environmental history. Many scientists studied Ice Complex deposits on Bykovsky Peninsula, but systematic multidisciplinary investigations were not accomplished until recently.

In 1998-2000, Russian-German teams studied these excellent paleoenvironmental archives using a multidisciplinary research concept (Siegert et al., 1999a, b; Sher et al., 2000; Schirrmeister et al., 2001). It was aimed to obtain a more comprehensive picture of the Late Quaternary environmental and climate development by analyzing more or less independent sequences of data. This paper summarizes the most important environmental evidence obtained by different methods. An initial complex reconstruction will be attempted, using the best data from various disciplines. 


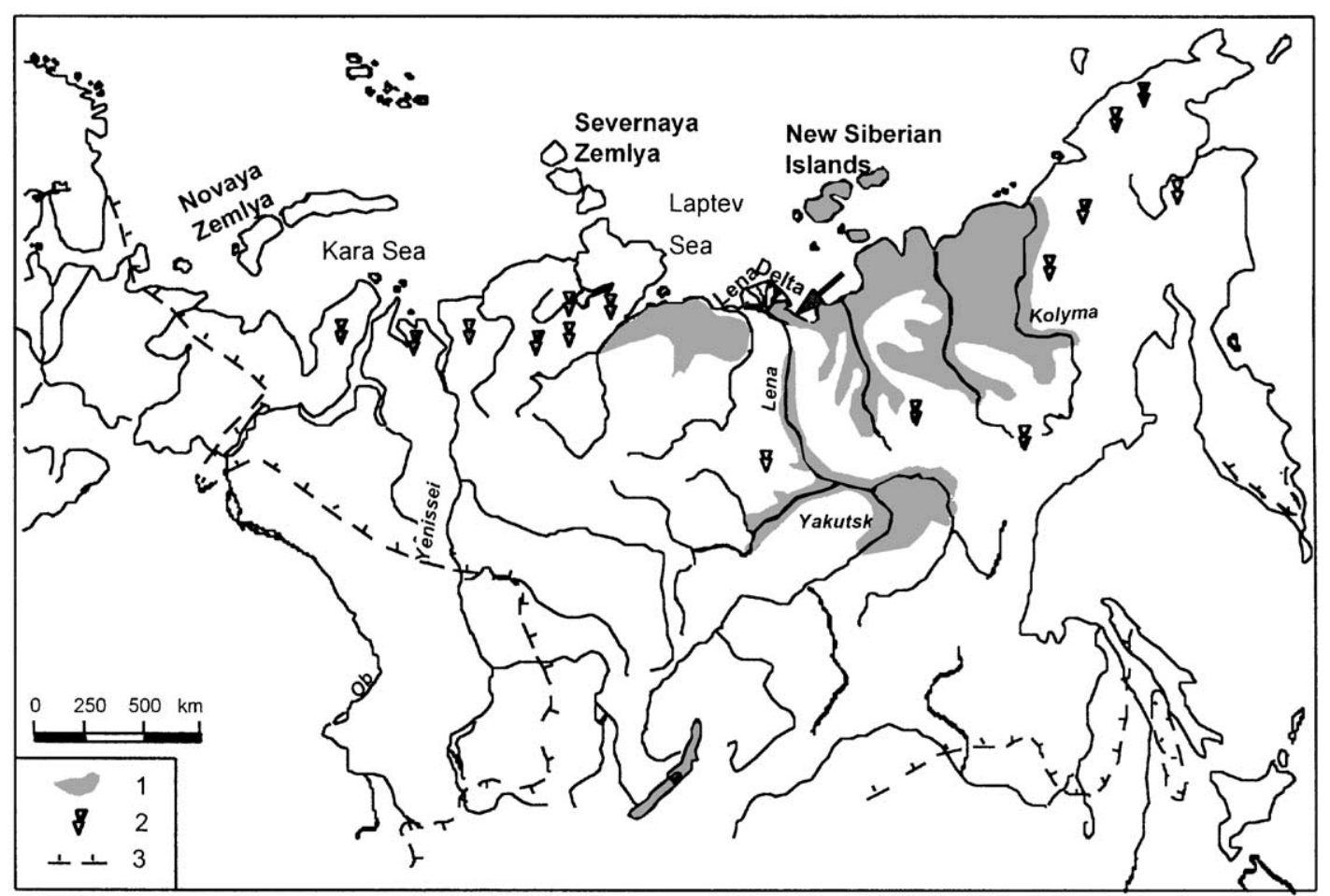

Fig. 1. Schematic Map of Ice Complex distribution in Northern Siberia (according to Romanovsky, 1993): 1—Areas with widespread Ice Complex on different relief elements; 2-Areas with Ice Complex spread in river valleys, deltas and at lake plains; 3 - Southern boundary of recent permafrost.

\section{Methods}

A number of different approaches have been chosen to study the permafrost sequences (Table 1). Geocryological studies explore the structure of ground ice. Lithological analyses are used for sediment characteristics and facies differentiation. The geochemical and mineralogical compositions of permafrost deposits reflect biological activities, pedogenetic processes, and the origin of clastic material. Pollen analyses give regional, more integral information about the Late Quaternary vegetation. However, carpological analyses (macrofossil plant remains) allow more detailed reconstruction of the local vegetation cover. Perennially frozen sediments in Arctic Siberia provide perfect preservation of the remains of various organisms, from large mammal bones to the smallest parts of insect chitin exoskeleton. These fossils provide independent information about fauna and environmental conditions (vegetation, soils, moisture supply etc.) and important proxy evidence for the reconstruction of past climate. Micropaleontological studies of soil rhizopods (testate amoebae) reflect moisture and temperature conditions in paleocryosols. Studies of mammal remains show the composition and density of the Late Pleistocene "Mammoth" fauna. Paleoentomological investigations indicate the temperature and moisture conditions on the soil surface. While the different bio-indicators mainly reflect summer conditions, the stable isotope composition of ice wedges $\left(\delta^{18} \mathrm{O}, \delta \mathrm{D}\right)$ gives us information on winter climate conditions. Differences result from the use of numerous paleoenvironmental and climate indicators on different levels. However, only in this way can we approximate the actual conditions existing in the past.

\section{Geologic-geomorphologic situation}

The Bykovsky Peninsula is located adjacent to the Kharaulakh coastal ridge and is a relict of a larger foreland area of these mountains. Thermokarst relief mainly characterizes the recent landscape, composed of three geomorphologic elements: the Ice Complex to elevations at about $40 \mathrm{~m}$ a.s.l.; many lakes within sediment-filled thermokarst depressions (alasses); and thermo-erosional channels (logs). The coastal cliff "Mamontovy Khayata" and its surroundings were the subject of study (Fig. 2).

\section{Composition of permafrost deposits}

Modern thermo-erosional processes of the coastal cliff have exposed three different types of deposits corresponding to the geomorphological elements. The Ice 


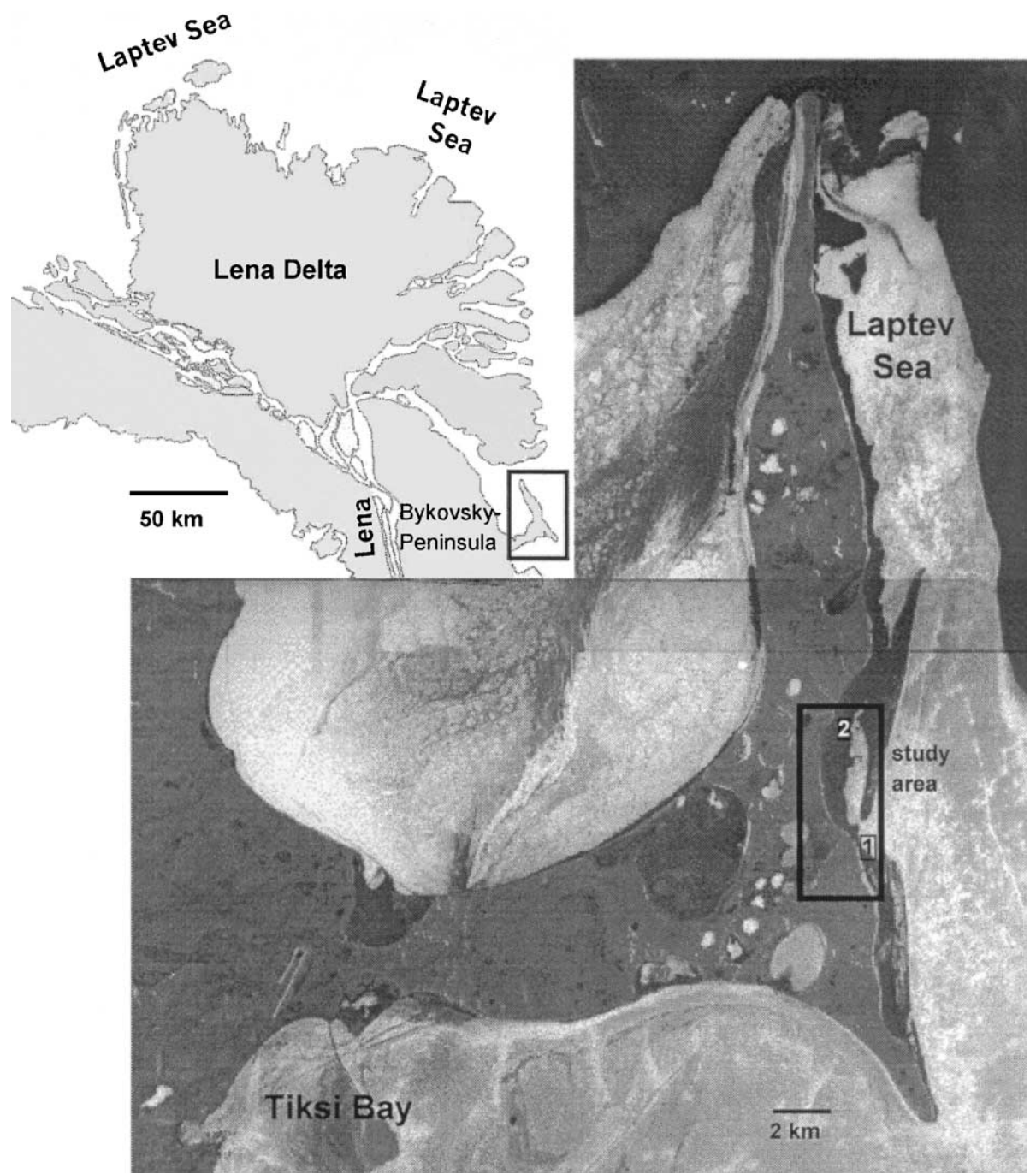

Fig. 2. Satellite picture of the Bykovsky Peninsula and the position of the study area (Corona satellite, June, 1964); 1-Section "Mamontovy Khayata", 2-Section "Mamontovy Bysagasa".

Complex deposits with large ice wedges (up to $40 \mathrm{~m}$ high and 5-6 $\mathrm{m}$ wide) represent the main part of the profile. The Ice Complex in the section "Mamontovy Khayata" consists predominantly of ice-rich silty sandy deposits. The Ice Complex sequence is subdivided into three units (A, B, C) (Fig. 3). Strong peatification and the presence of numerous peaty paleosols characterize the middle part (unit B, 10-25 $\mathrm{m}$ a.s.1.). In contrast, the lower part (unit $\mathrm{A}, 0-10 \mathrm{~m}$ a.s.l.) and the upper part (unit $\mathrm{C}$, 25-35 $\mathrm{m}$ a.s.1.) contain less peaty material and plant fossils and are only slightly influenced by soil formation. The Ice Complex is overlain by a $1-2 \mathrm{~m}$ thick sandy horizon (unit $\mathrm{D}, 35-38 \mathrm{~m}$ a.s.l.). It is bound laterally by sandy alas deposits of a thermokarst depression (unit F) and is covered by sandy sediments formed by thermoerosional processes (unit E, $10-15 \mathrm{~m}$ a.s.1.).

In general, the deposits contain large amounts of ground ice in the form of massive polygonal ice wedges and segregated ice in the sediment. The ice content of the intrapolygonal sediment blocks varies between $80 \%$ and $180 \%$ (ice content in relation to dry weight of the sediment). Paleosol horizons enriched in organic matter are characterized by smaller ice contents as compared to mineral interlayers and sediment horizons slightly influenced by soil formation. The observed thick-banded and lens-like reticulated cryostructure is typical for sediments formed in poorly drained landscapes with a near-surface permafrost table (Katasonov, 1975; French, 1996). The deposits, especially paleosols, are disturbed by cryoturbation features with heights of $0.5-1 \mathrm{~m}$. The banded sediment cryostructure is bent upward up to $2 \mathrm{~m}$ from the horizontal position along the contacts with ice wedges. Schirrmeister et al. (2001) and Siegert et al. (2001) present a more detailed cryolithological description. 
Table 1

Overview of the applied methods with reference to special publications

\begin{tabular}{|c|c|c|c|}
\hline Methods & Study subjects & Equipment & References \\
\hline $\begin{array}{l}\text { Radiocarbon age determination } \\
\text { (AMS, conventional) }\end{array}$ & Plant remains, bones & $\begin{array}{l}\text { Finnigan MAT Delta E gas isotope ratio } \\
\text { mass } \\
\text { spectrometer }\end{array}$ & $\begin{array}{l}\text { Schirrmeister et al. (2001), } \\
\text { Nadeau et al. (1997, 1998) }\end{array}$ \\
\hline Grain size analysis & Permafrost sediments & Laser particle analyzer LS 200, Fa. Coulter & Siegert et al. (2001) \\
\hline Heavy mineral analysis & Permafrost sediments & & Siegert et al. (2001) \\
\hline $\begin{array}{l}\text { Geobiochemical investigations } \\
\left(\mathrm{TOC}, \mathrm{TC}, \mathrm{N}, \mathrm{S}, \delta^{13} \mathrm{C}\right)\end{array}$ & Organic matter & $\begin{array}{l}\text { CS-Autoanalyzer (ELTRA CS 100/1000 S); } \\
\text { CNS Microanalyzer (LECO 932) } \\
\text { Finnigan MAT Delta-S IR-MS + Heraeus } \\
\text { elemental analyzer }\end{array}$ & Schirrmeister et al. (2001) \\
\hline $\begin{array}{l}\text { Mass specific magnetic } \\
\text { susceptibility }\end{array}$ & Permafrost sediments & Bartington MS 2 & Schirrmeister et al. (2001) \\
\hline Pollen analysis & $\begin{array}{l}\text { Tree and herb pollen, } \\
\text { sporomorphs }\end{array}$ & Axioskope 2 & Andreev et al. (2001a) \\
\hline Carpological studies & Seeds, plant macrofossils & $\begin{array}{l}\text { Fa. Carl Zeiss Jena } \\
\text { Stereomicroscope SV } 12 \\
\text { Fa. Carl Zeiss Jena }\end{array}$ & Kienast et al. (2001) \\
\hline Micropaleontological studies & Testate amoebae & $\begin{array}{l}\text { Axioskope } 2 \\
\text { Fa. Carl Zeiss Jena }\end{array}$ & Bobrov et al. (1999) \\
\hline Paleozoology & $\begin{array}{l}\text { Mammal bones and tooth } \\
\text { Insects }\end{array}$ & & Kuznetsova et al. (2001) \\
\hline Stable isotopes $\left(\delta^{18} \mathrm{O}, \delta \mathrm{D}\right)$ & Ice wedges & $\begin{array}{l}\text { Finnigan MAT Delta-S IR-MS with } 2 \\
\text { equilibration units }\end{array}$ & Meyer et al. $(2000,2001 \mathrm{a}, \mathrm{b})$ \\
\hline
\end{tabular}

\section{Radiocarbon age scale}

Altogether, 70 AMS-ages and 20 conventional age determinations of plant remains were used for a chronological differentiation of the permafrost deposits. The Ice Complex (units A, B, C) and its younger cover (unit D) were continuously accumulated during the last $60 \mathrm{kyr}$ (Fig. 4). The oldest radiocarbon data is $58,400+4960 /$ -3040 (KIA 6730). We consider the maximal rounded age to be about $60 \mathrm{kyr}$ BP. The details of the Leibniz Laboratory AMS procedures are given by Nadeau et al. $(1997,1998)$. Ice Complex formation continued during the Last Glacial Maximum (LGM) until the early Holocene. This means that an extensive glaciation could not have taken place in the study area. The deposits of the thermokarst depression (unit E) were dated between 10 and $3 \mathrm{kyr}$ BP. The sediments of the thermokarst valley (unit F) were accumulated between 4 and $1 \mathrm{kyr}$ BP. The age determinations are documented in detail by Schirrmeister et al. (2001). The age/height relationships of in situ organic remains show a good correlation (Fig. 4). The presented regression equation helps to estimate the ages of undated samples with a standard deviation of about $1 \mathrm{kyr}$. Therefore, the different results of geochemical, sedimentological and paleo-ecological studies can be put into a wellfounded chronology. Some of the in situ bone dates are well correlated with this age sequence. Previous cores taken in front of the section "Mamontovy Khayata" (Grigoryev, 1993) penetrated Ice Complex deposits up to $15 \mathrm{~m}$ below sea level, indicating that the Ice Complex has been forming since about $80 \mathrm{kyr}$ BP.

\section{Sedimentological characteristics of the different units}

Grain size analyses indicate that the Ice Complex deposits are composed of poorly-sorted sandy silt and that their Holocene cover consists of fine- to middlegrained sand. Although the general accumulation does not vary greatly, there is a large spectrum of different fine-grained silty sands. Unit A is considered to have been formed mainly by fluvial processes (Siegert et al., 2001). The main distinctive feature of this unit is the relatively high magnetic susceptibility (Fig. 5). Units B, $\mathrm{C}$ and $\mathrm{D}$ are considered as polygenetic formations, in which primarily accumulated material was repeatedly reworked and redeposited by surface water, solifluction, nival processes around snow fields, and perhaps by wind. The noticeable differences in grain size distribution were also connected with the alternating runoff of meltwater from the Kharaulakh Ridge. The higher contents of coarse grains point to the PleistoceneHolocene transition about $12 \mathrm{kyr}$ BP.

The mineral composition of the Ice Complex deposits is characterized by low heavy mineral contents, mostly $<1 \%$. The light mineral fraction mainly consists of rock fragments of slates, sandstones and quartzites, of feldspars and low proportions of quartz. Minerals of the amphibole and pyroxene groups dominate the heavy mineral fraction. Ilmenite, leucoxene, and epidote were also determined, followed by garnet, apatite and titanite (sphene). Small amounts of zircon and tourmaline are always present (for more detailed results, see Siegert et al., 2001). These mineral compositions resemble those 

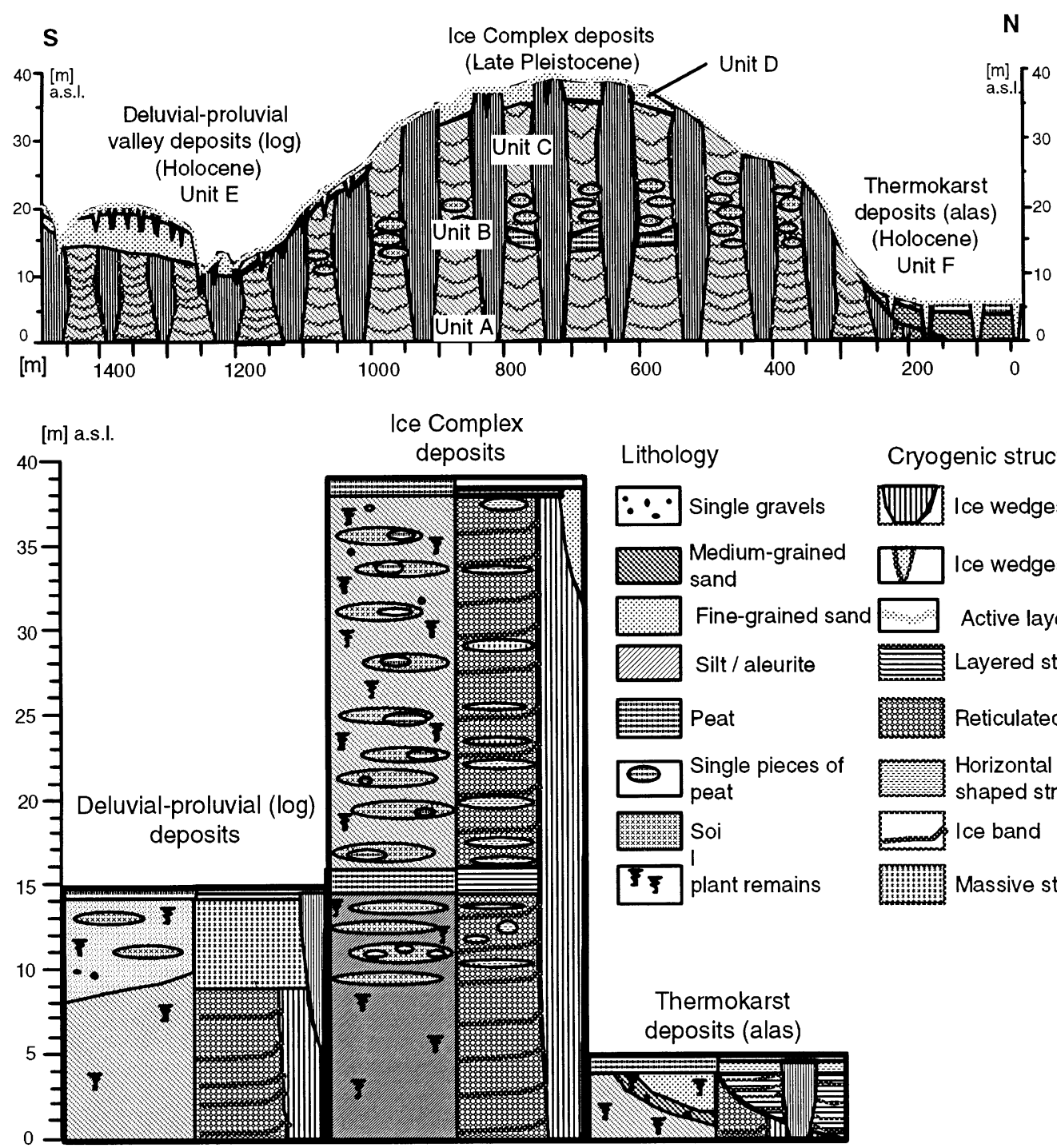

Fig. 3. Schematic profile and the cryolithological composition of the study section "Mamontovy Khayata", Bykovsky Peninsula.

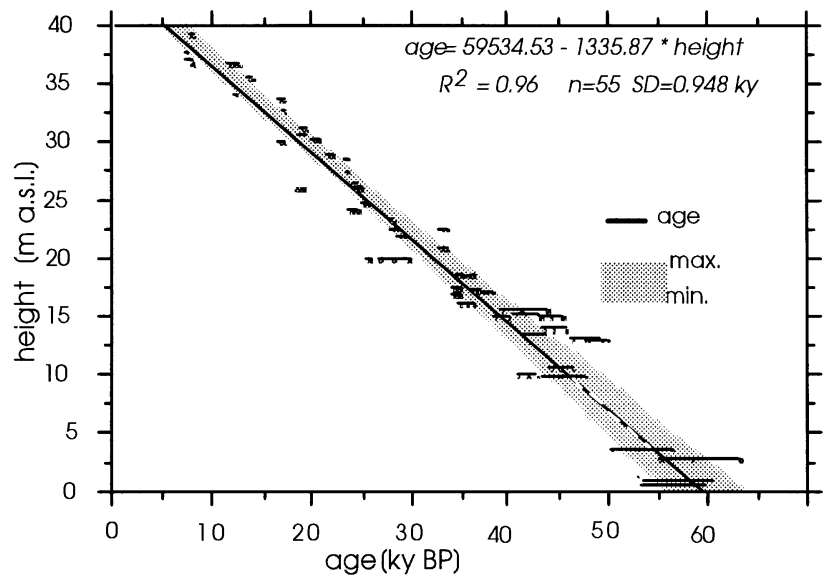

Fig. 4. Age-height relation of the continuous Ice Complex sequence and the Holocene cover scatter diagram with regression, $95 \%$ confidence bands. of the covering sediments in the Kharaulakh Ridge (Fig. 5). In contrast, sediments of the Lena Delta, which are considered to be one of the sources of the Ice Complex formation (Nagaoka et al., 1995), have more amphiboles and garnets and quite different pyroxene content. Such a close genetic connection of the heavy mineral association between the Ice Complex deposits and the surrounding mountains is also reported from the third terrace of the western Lena Delta and the Chekanovsky ridge (Schwamborn et al., 2001a). According to grain size and mineral analyses, no substantial facies change had taken place during the Late Pleistocene (Table 2). The clastic matter was mainly transported from the nearby Kharaulakh Ridge. There are no clear signals for larger long-distance eolian or fluvial transport. 
The four units of the "Mamontovy Khayata" Ice Complex are also differentiated by geobiochemical data (Fig. 5). Limited accumulation of organic matter and limited decomposition under dry, dominantly aerobic conditions characterize the lower unit A (60-52 kyr BP). A stronger alternation of biogeochemical data is typical for unit B (48-28 kyr BP). High TOC values connected with high $\mathrm{C} / \mathrm{N}$ relations and low $\delta^{13} \mathrm{C}$-values (more negative) reflect a lower decomposition of organic matter under anaerobic conditions. Unstable surface conditions are connected with local thermokarst processes and higher soil moisture as well as stronger bioproductivity and pedogenesis. At about $28 \mathrm{kyr} \mathrm{BP}$ (unit C 28-12 kyr BP) the recorded values change clearly, compared with unit B. Low TOC-contents and low variations indicate stable conditions with reduced biological activity. Low $\mathrm{C} / \mathrm{N}$ ratios and high $\delta^{13} \mathrm{C}$-values reflect relatively dry, aerobic conditions. The values of the Holocene deposits (units D, E, F) are comparable with those of unit B. Increased humidity supported the growth of peat. The thermokarst processes led to unstable surface conditions.

The variations in the TOC content, $\mathrm{C} / \mathrm{N}$ ratio and $\delta^{13} \mathrm{C}$ values of bulk organic matter seem to be connected with differences in the intensity and character of soil formation and peat accumulation as well as variations in plant associations. Variations in the magnetic susceptibility and grain size distribution reflect different sediment sources as well as changes in transport conditions. There are two stages with relatively low variations in the environmental conditions (unit $\mathrm{A}$ 60-52 kyr BP, unit C $28-12 \mathrm{kyr}$ BP) and two stages with obviously unstable conditions (unit B about 48-28 kyr BP, unit D since about $12 \mathrm{kyr} \mathrm{BP)}$.

\section{Paleobotanical results}

\subsection{Pollen}

Palynological studies yield the vegetation history during the last $60 \mathrm{kyr}$. Large amounts of reworked indeterminable pre-Quaternary Pinaceae characterized unit A (Fig. 6). This indicates intense denudation of the pre-Quaternary deposits, which are widespread in the coastal ridges near Tiksi. This is in agreement with the supposed fluvial character of the lowest Ice Complex deposits. The high contents of reworked material probably also indicate a scarce vegetation cover around the site, as well as erosion in the denudation area. A relatively high content of green algae colonies (Pediastrum and Botryococcus) suggests a shallow water environment during sedimentation. According to pollen spectra, sparse grass and sedge communities dominated the vegetation ca. 60-53 kyr BP. The climate probably was cold and dry (Table 2 ).
The dominance of Poaceae and Cyperaceae pollen with some Caryophyllaceae, Asteraceae, Artemisia, and Saxifraga is typical in the samples, which were dated to 48-33.5 kyr BP. Some shrub taxa pollen (Salix, Betula sect. Nanae, and Alnus fruticosa) are present in the spectra as well. Selaginella rupestris spores, indicators of a very dry environment, are also common in the spectra. A relatively high concentration of redeposited Pinaceae pollen in the samples, dated to $48-42.5 \mathrm{kyr} \mathrm{BP}$, is probably evidence for a rather sparse vegetation cover at this time and for intense erosion of pre-Quaternary deposits in the surrounding area.

The pollen spectra show that open tundra-like Poaceae and Cyperaceae associations, with other herbs including Asteraceae, Ranunculaceae, and Cichoriaceae, dominated in the area about $48-42.5 \mathrm{kyr}$ BP. Steppe-like communities with Artemisia and shrubby tundra communities with Salix and Betula sect. Nanae also were present in the vegetation cover. Later, from 42.5 to $33.5 \mathrm{kyr} \mathrm{BP}$, the vegetation cover was probably denser. The increase in the pollen taxon diversity, reflecting higher species diversity in the vegetation cover, is also evidence for rather favorable climate conditions. The climate was dry, but relatively warm, especially from 42.5 to $33.5 \mathrm{kyr}$ BP. A high concentration of Pediastrum colony remains and the permanent presence of Botryococcus indicate shallow water bodies. The warmer interval corresponds with the optimum of the middle Kargin Interstadial (Malokhetskii warm interval) (Kind, 1974; Kaplina et al., 1978; Isaeva, 1984; Lozhkin, 1987; Anderson and Lozhkin, 2001).

There are only two radiocarbon-dated samples $(28,470 \pm 160$ and $28,110+230 /-220 \mathrm{yr} \mathrm{BP})$ for the 33.5-25.6 kyr BP interval. Poaceae and Cyperaceae with Caryophyllaceae, Asteraceae, and Ranunculaceae dominated the pollen spectra, while the content of Artemisia pollen decreased. Peaks of Selaginella rupestris (indicator of dry exposed soils) and Equisetum (indicator of exposed, disturbed soils) spores are notable in the spectra. The pollen spectra suggest that open Poaceae and Cyperaceae associations with some other herbs like Caryophyllaceae, Asteraceae, and Ranunculaceae dominated. The climate was dry and relatively cold. This period may be connected with a climate deterioration (Konoshelskii cool interval) that had been noted about 33-30 kyr BP in the adjacent regions (Kaplina and Giterman, 1983; Isaeva, 1984, Lozhkin, 1987; Anderson and Lozhkin, 2001; Andreev et al., 2001a) as well as the Zhigansk glaciation in the Verkhoyan Mountains (Kind et al., 1971).

The pollen spectra, radiocarbon-dated to $25.6-16 \mathrm{kyr}$ $\mathrm{BP}$, contain many reworked indeterminable Pinaceae pollen grains that may reflect low pollen productivity in the local plant communities and/or a sparse vegetation cover. It can be assumed that scarce steppe-like Poaceae communities with some 


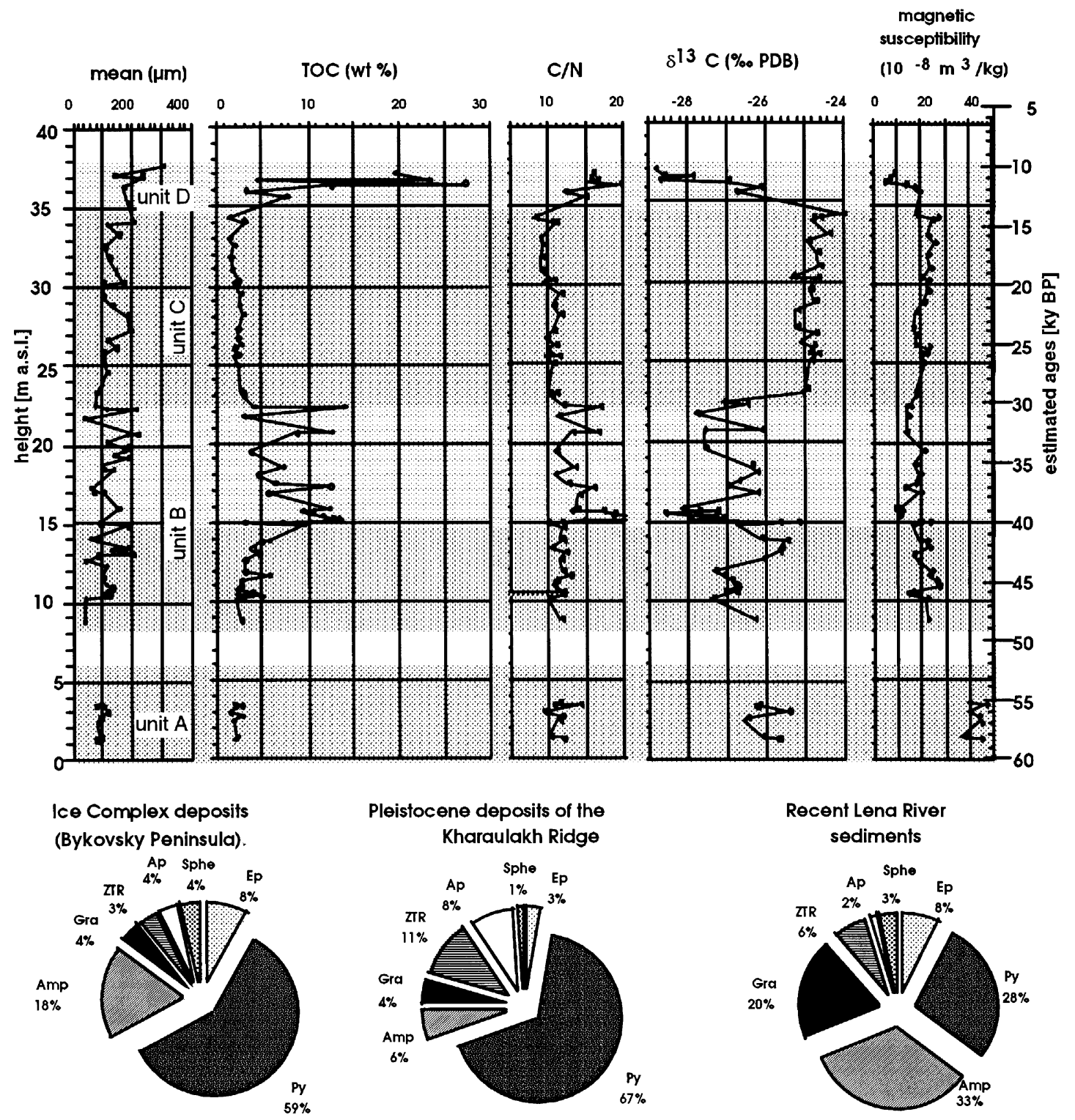

Fig. 5. Sedimentological characteristics of Ice Complex deposits and the heavy mineral association of Ice Complex deposits in comparison with deposits from Kharaulakh Mountains and Lena River sediments (Gra—garnet; ZTR—zircon, tourmaline, rutile; Ap—apatite; Sphe—sphene; Ep-epidote; Py-pyroxene; Amp - amphibole).

Caryophyllaceae, Asteraceae, and Cichoriaceae covered the Bykovsky Peninsula. The increase in Cichoriaceae and Selaginella rupestris percentages proves that disturbed, exposed soils were also common in the area. A relatively high content of Pediastrum and Botryococcus colonies indicates the existence of shallow water.

Pollen spectra dated to $15-12 \mathrm{kyr}$ BP are characterized by some decrease of reworked Pinaceae pollen, decreased Selaginella rupestris spores and green algae colonies contents, and a slight increase of Cyperaceae and Ericales pollen contents. These changes suggest a denser vegetation cover than during the LGM, although a high amount of Encalypta spores in the upper part of the zone indicates the presence of distributed soils in the area. A slight increase in Ericales and Cyperaceae probably reflects some amelioration of climate at this time. According to the pollen spectra, the maximum warming was about $12 \mathrm{kyr} \mathrm{BP}$. This warming may correlate with the Allerød.

Pollen spectra dated to $8.2-4.5 \mathrm{kyr} \mathrm{BP}$ are characterized by dramatic increases of Betula sect. Albae, B. sect. Nanae, Alnus fruticosa, Salix, and Ericales pollen contents. Such changes suggest that shrubby tundra and/or open birch forest (?) was widely distributed on the Bykovsky Peninsula during the early Holocene. The high tree pollen percentages in the spectra reflect that the climate conditions were most favorable during that time interval. The data are in good agreement with other 


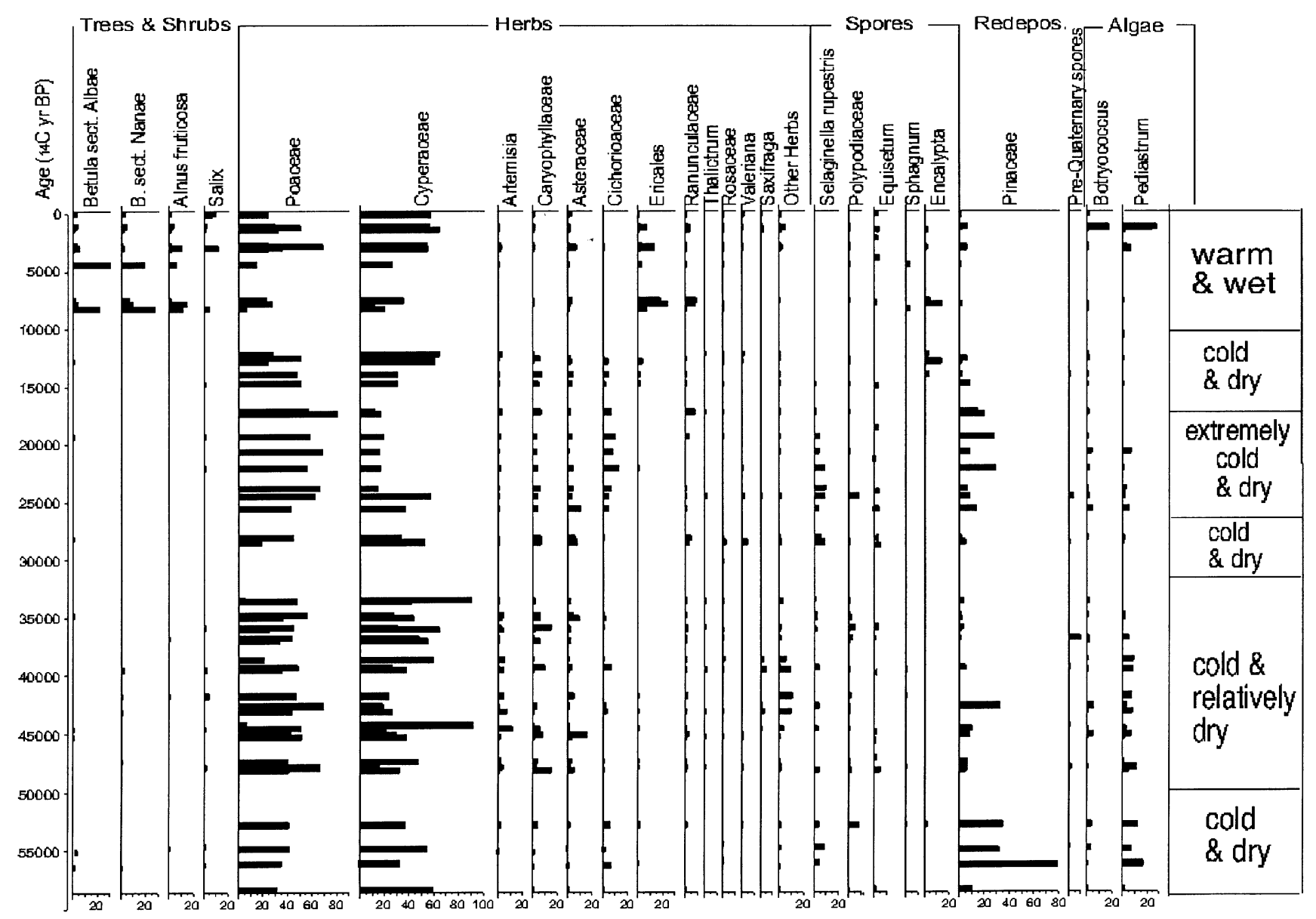

Fig. 6. Generalized pollen and spore diagram of some selected taxa of the section "Mamontovy Khayata", Bykovsky Peninsula.

pollen records from the region (Andreev et al., 2001b; Pisaric et al., 2001; Schwamborn et al., 2001a,b). A relatively high amount of Encalypta spores reflects the presence of distributed soils caused by solifluction and thermal erosion processes in the area about 8.2-7.8 kyr BP.

The pollen spectra from the upper part of the diagram dated $4.5 \mathrm{kyr}$ BP to modern times are characterized by a decrease of Betula sect. Albae, B. sect. Nanae, and Alnus fruticosa pollen content, while the role of long-distance transported pollen of Picea and Pinus increases in the spectra. The vegetation became similar to that of modern times at the beginning of the Subboreal period, after $4.5 \mathrm{kyr}$ BP. These data are in good agreement with regional pollen records from the area (Andreev et al., 2001b; Pisaric et al., 2001; Schwamborn et al., 2001a, b). Such changes reflect a deterioration of the climate about that time.

\subsection{Plant macrofossils}

Plant macrofossil studies yield a more detailed view of the local vegetation composition (Fig. 7). Only a few identifiable plant remains are found in the sediments of unit A, dated ca. 58-53 kyr BP. Cold- and dry-resistant pioneer plants (Papaver sect. Scapiflora, Orostachys spinosa, Draba sp., Minuartia rubella, Cerastium sp., Potentilla sp. and Cassiope tetragona) dominated the species spectrum. The occurrence of Carex sect. Boerneri emphasizes the predominance of dry conditions. One sample of unit A contains remains of Ranunculus reptans indicating moist silty or sandy areas, flooded in spring but drying out in summer. The results indicate a very sparse vegetation cover and cold and dry climate during that time (Table 2). This is in good agreement with the results of pollen analysis.

The cold- and dry-resistant pioneer plants mentioned above as well as Kobresia myosuroides dominated in the sediments dated ca. 48-43 kyr BP (lowermost part of unit B), but tundra bog plants and even true water plants have also been found. This is especially remarkable as these water plant species either do not occur so far north nowadays or at least do not produce seeds. That means that the small water bodies existed long enough and were sufficiently heated for bloom and seed maturation of Potamogeton vaginatus, $P$. pectinatus, 


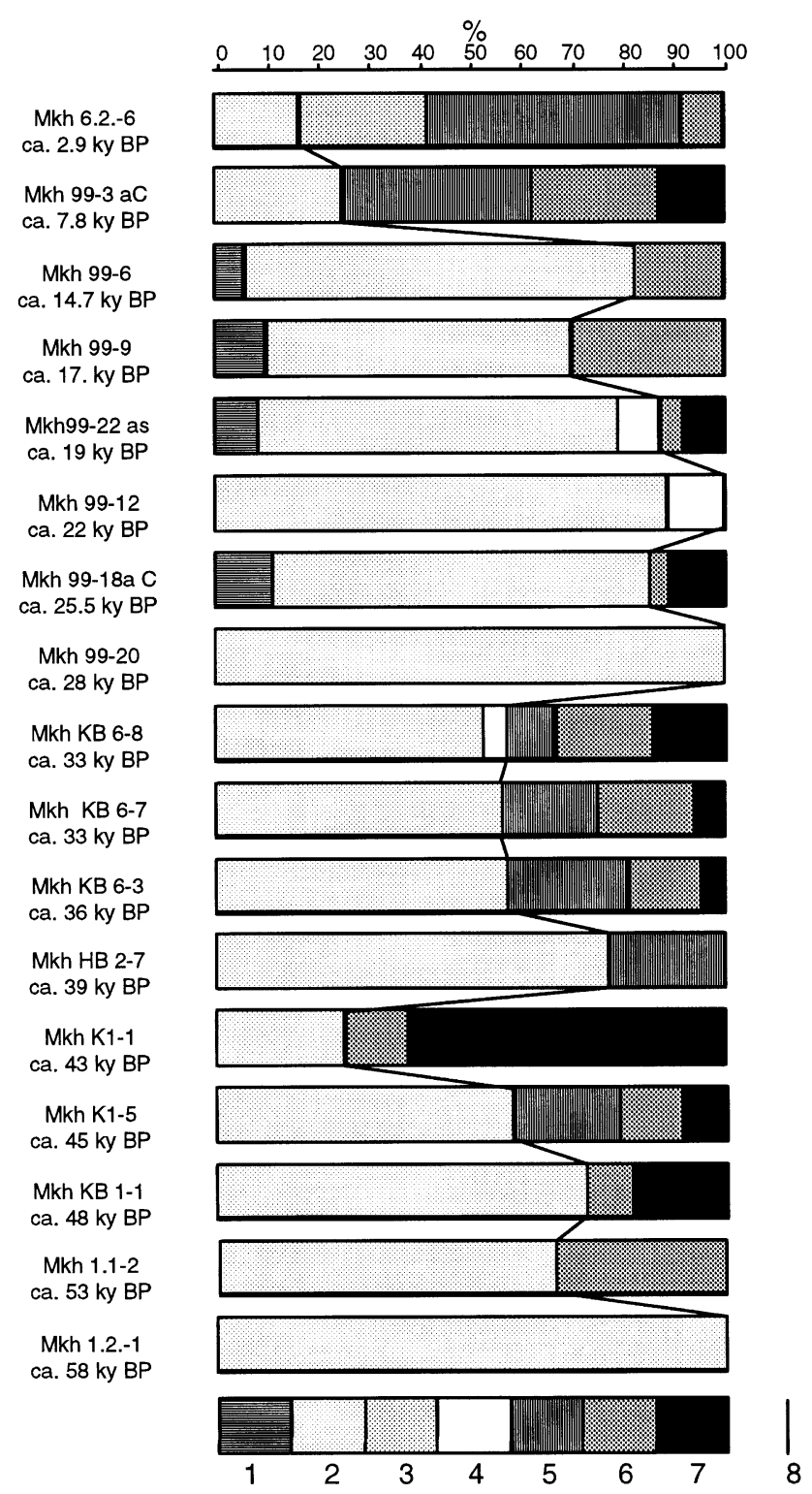

Fig. 7. Composition of plant macrofossils during Late Quaternary on the section "Mamontovy Khayata", Bykovsky Peninsula; 1 - thermophilous ruderal plants of dry sandy habitats, 2-cryoxerophilous pioneer vegetation and tundrasteppe vegetation, 3-snowfield habitats, 4-halophytes, 5-tundra bog vegetation, 6-plants of marshy sites at shallow water lake shores, 7 -water plants, 8 -line between indicators of xeric and moist conditions.

Sparganium minimum and Callitriche hermaphroditica, presently growing at this longitude only in central Yakutia (Hulten and Fries, 1986). A mosaic-like distribution is indicated, ranging from extremely dry to submersed habitats. It seems that the summer temperatures and moisture were significantly higher than today.

Some cold episode is reflected in a sample dated to 39 kyr BP. Among abundant moss remains only ArcticAlpine ruderal plants (Papaver sect. Scapiflora, Oros- tachys spinosa, Draba sp., Minuartia rubella) were found as well as some typical tundra bog plants like Carex stans, C. aquatilis, and C. bigelowii-type. The climate was still moist but too cold for seed maturation of water plants.

The species diversity increased again at about 36 to $33 \mathrm{kyr}$ BP. Representatives of both tundra-steppe (Kobresia myosuroides, Carex Sect. Boerneri, Orostachys spinosa) and wet places like floodplains (Senecio congestus, Ranunculus reptans, Caltha palustris), tundra bogs (Carex aquatilis, Eriophorum scheuchzeri) and ponds (Callitriche hermaphroditica, Potamogeton vaginatum, Batrachium sp.) prove the coexistence of dry and wet habitats. In one sample, Callitriche hermaphroditica becomes absolutely predominant. The summer temperatures had to be high enough for a sufficiently long time interval to free the water bodies from ice. The precipitation must have been sufficient to prevent drying out of lakes in summer.

The oldest sample of unit C (28-15 kyr BP) dated to $28 \mathrm{kyr}$ BP resembles samples from unit A in botanical composition and ecological indication. This suggests a strong deterioration of the environmental conditions. The complete absence of any moisture indicators points to very dry conditions. However, the appearance of Berteroa incana and Raphanus raphanistrum in the following sample proves summer heating until ca. $25.5 \mathrm{kyr}$ BP. Today, both species occur further to the south. True water plants appear sporadically, depending on the continuity of water bodies. A salt indicator Spergularia salina proved salt enrichment due to the drying out in summer. Thus, moisture (and not heat) was the limiting factor. Both moisture and temperature conditions fluctuated during this period, but generally, it was dry and relatively warm in summer.

The plant composition of unit $\mathrm{D}$ deposits suggests that a significant increase of humidity took place at about $7.8 \mathrm{kyr}$ BP and subsequently a decrease in summer temperatures after $2.9 \mathrm{kyr} \mathrm{BP}$. Two species of water plants were found: Batrachium sp. and Potamogeton sp. although in very small amounts. The deterioration of environmental conditions in the Arctic during the late Holocene is evident from the youngest deposits. Tundra bog plants dominated the plant fossil spectrum. Exotics from south have not been found. The occurrence of plants from snow fields like Saxifraga nivalis and Ranunculus nivalis indicates a short growing season due to a thick snow cover and predominating cool and moist conditions.

In summary, the conditions for Arctic flora seem to have been more favorable in the Pleistocene. The summer temperature had increased and the growing season was extended, compared to the recent situation. During Late Pleistocene the climate was arid rather than mesic. This is explainable by the higher degree of continentality due to position of the coastline, which 
was located several hundred kilometres further to the north during the Late Pleistocene. Warm summers and a sufficiently high amount of precipitation characterized the Middle Weichselian whereas the Late Weichselian (Sartan) was rather xeric, but the warm conditions in summer persisted most of the time. Several times the favorable climatic stages have suddenly been interrupted by short stages of climatic deterioration. During the Holocene a radical transformation of the environmental conditions of the Siberian Arctic took place, causing a considerable impoverishment of plant communities. The climatic regime was characterized by the rise of humidity and lower summer temperatures.

\section{Testate amoebae (Protozoa: Testacea)}

One possibility to get more information about soil temperature and moisture is the study of rhizopods (testate amoebaes) living in permafrost soils (Bobrov et al., 1999). Four different ecological groups were distinguished reflecting special ecological conditions (Fig. 8a). The oldest shell amoebae were discovered in a sample radiocarbon-dated to ca. $53 \mathrm{kyr}$. Soil and euribiont species typical for hydromorphic mineral soils dominated in the spectrum. There are numerous remains of Centropyxis plagiostoma (calciphyte) indicating the mesotrophic character of nutrition.

In the period from about 45.3 to $43 \mathrm{kyr} \mathrm{BP}$, there are numerous remains of rhizopod species which are typical for wet Sphagnum and acid humus locations in the modern tundra zone (genera Arcella, Centropyxis, Cyclopyxis, Plagiopyxis, Argynnia). Remains of Centropyxis plagiostoma (calciphyte) indicated the mesotrophic character of nutrition in this period. Temperature conditions were relatively favorable for rhizopods. The content of soil and euribiont species significantly
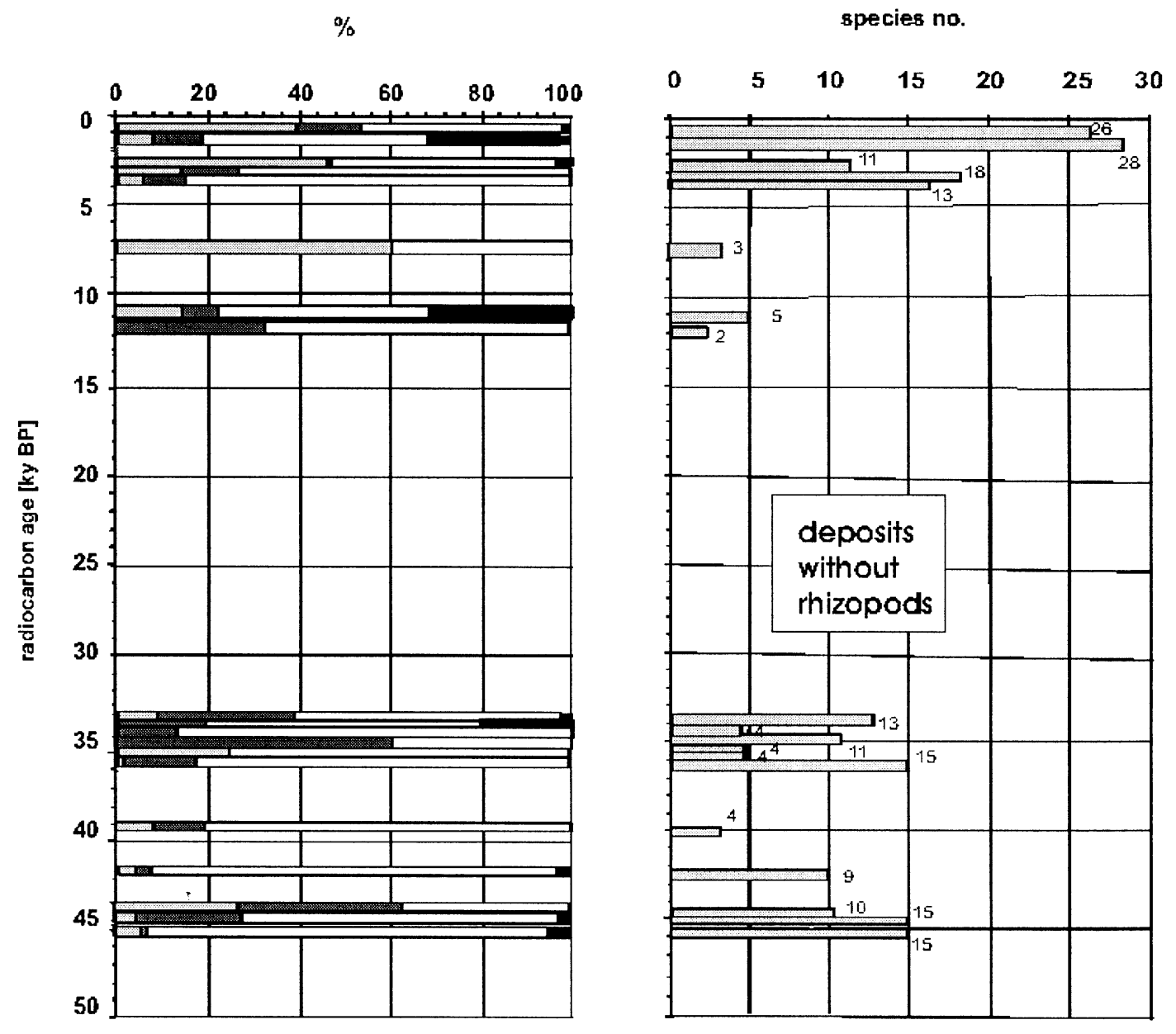

$\square$ Group A Group B $\square$ Group C Group D

Fig. 8. (a) The structure of ecological groups of rhizopods during Late Pleistocene and Holocene on the section "Mamontovy Khayata", Bykovsky Peninsula (Group A-hygrophilous and hydrophilous species; Group B-calciphilous species; Group C-euribiont and soil species; Group D-sphagnouphilous species) and the diversity of testate amoebae (Testacea, Protozoa) species in the samples from Bykovsky Peninsula. (b) The number of species of rhizopod during Late Pleistocene and Holocene on the section "Mamontovy Khayata", Bykovsky Peninsula. 
increased at about $42 \mathrm{kyr} \mathrm{BP}$, probably reflecting drier conditions (Table 2).

During the next stage, between 39.3 and $35 \mathrm{kyr} \mathrm{BP}$, hygrophilous and hydrophilous species are absent in more than half of the samples (Fig. 8a), reflecting a dry environment. The species diversity is also rather poor (Fig. 8b). However, this as well as the structure and complexity of the rhizopods associations increased towards the end of this interval. Generally, it was drier and colder than in the interval of about $45.3-43 \mathrm{kyr}$ BP. All groups of rhizopods appeared in the sample radiocarbon-dated to $33,450 \mathrm{yr} \mathrm{BP}$. This time must have been quite favorable for testate amoebae.

Only few rhizopods remains were found in the samples dated between 33.4 and $12.2 \mathrm{kyr} \mathrm{BP}$. A very limited number (from 2 to 6) of soil and euribiont species are represented only by several minor forms reflect probably extremely cold and dry conditions.

Hygrophilous, hydrophilous, and sphagnophilous species are absent in the sample dated to $12.2 \mathrm{kyr} \mathrm{BP}$. The soil climate was still very dry. But about two hundred years later, all groups of rhizopods appear in a sample radiocarbon-dated to $12 \mathrm{kyr} \mathrm{BP}$ (beginning of Allerød). Climate conditions were favorable for testate amoebae during that time. Only hydrophilous and euribiont species were observed in the samples dated to $7.5 \mathrm{kyr} \mathrm{BP}$. The species diversity is very limited (Fig. 8b). The soil climate was wet and probably cold (swampy depressions).

Late Holocene (ca. $4.5 \mathrm{kyr}$ BP-modern time) deposits are characterized by the presence of raw-humophilic and sphagnophilic rhizopods both xerophilous genus (Valkanovia, Assulina, Corythion, Nebela) and hydrophilous species (Centropyxis and Difflugia genera). Mesotrophic rhizopods were also broadly distributed at that time. Generally, all ecological groups of shell amoebae were present during Late Holocene (Fig. 8a). The species composition is also quite varied during that interval (Fig. 8b). Probably it reflects the specific feature of late Holocene ecological conditions, which consist in a contrasting alternation of moisture conditions.

The main characteristic of fossil rhizopod complexes of Bykovsky Peninsula is the dominance of stenotopic species. It may be a sign of temperature, moisture, and nutrient regime stability during the climate amelioration periods. The homogeneous dominant species complex in most samples may reflect similar climatic conditions in these periods.

\section{Paleozoological results}

\subsection{Mammals}

The earliest finding of an almost complete mammoth carcass (the "Adams' Mammoth" found in 1799) came from the thawing deposits of the Bykovsky Peninsula (Adams, 1807). In recent years, this Laptev Sea coastal site with its spectacular exposure of the Ice Complex attracted many researchers, partially because of its relatively easy accessibility. However, the total scope of previous paleontological and paleo-ecological research is absolutely insufficient. More than 1000 bones were collected with the active help of all colleagues during field activities from 1998 to 2000. All the identifiable fragments were registered to obtain as complete statistics of the species composition as possible. It is typical for permafrost regions that in summer fossil bones rapidly emerge from frozen sediments and are transported to the cliff foot by mudflows. Therefore, most bones come from the shore and shallow coastal bars (Kuznetsova et al., 1999), mainly in the area of the "Mamontovy Khayata" cliff and from "Mamontovy Bysagasa" to the northwest (Fig. 2). However, a rather large amount of bones (195) was collected at the "Mamontovy Khayata" exposure itself. About 24 bones were discovered strictly in situ.

In general, the summarized taxonomic composition of the Bykovsky Peninsula collection is typical for all known Ice Complex sites in Northeast Siberia. Woolly mammoth, horse, bison and reindeer dominate in the collection. The paleontological collection from Bykovsky Peninsula is unique not only because of the $100 \%$ registration of all the bone findings but also because of the comprehensive database of radiocarbon dates obtained from mammal bone collagen. For the first time we have such complete, well-dated material of Quaternary mammals from the Arctic region. L.D. Sulerzhitsky at the Geological Institute of the Russian Academy of Science, produced all age determinations within the framework of the project "System Laptev Sea 2000".

A total number of 78 samples were dated by the radiocarbon method. The conventional ${ }^{14} \mathrm{C}$ ages of two of the bones found in situ at the "Mamontovy Khayata" cliff correspond with AMS-dates of plant remains from the same level. The age distribution of bones from Bykovsky Peninsula is not homogeneous (Fig. 9). The largest amount of dates belongs to the period from 36 to $26.5 \mathrm{kyr}$ BP. The other dates concentrate in the period $15-12.5 \mathrm{kyr}$ BP. There are also two periods with only a few dates: 44.5-36 and 20-14.7 kyr BP. Such an uneven data distribution can be interpreted in two different ways. Firstly, it depends on the geological situation and secondly, on the number of animals in the region.

The different quality of the outcrop exposition was reflected in the number of collected bones and the data distribution. Generally, the lower part of the outcrop (from 0 to $14-15 \mathrm{~m}$ a.s.l.) was badly exposed. Only a few bones were collected from this part. This could explain the small number of bones dated to more than $36 \mathrm{kyr} \mathrm{BP}$ (Fig. 9). The heterogeneity of bone distribution also 


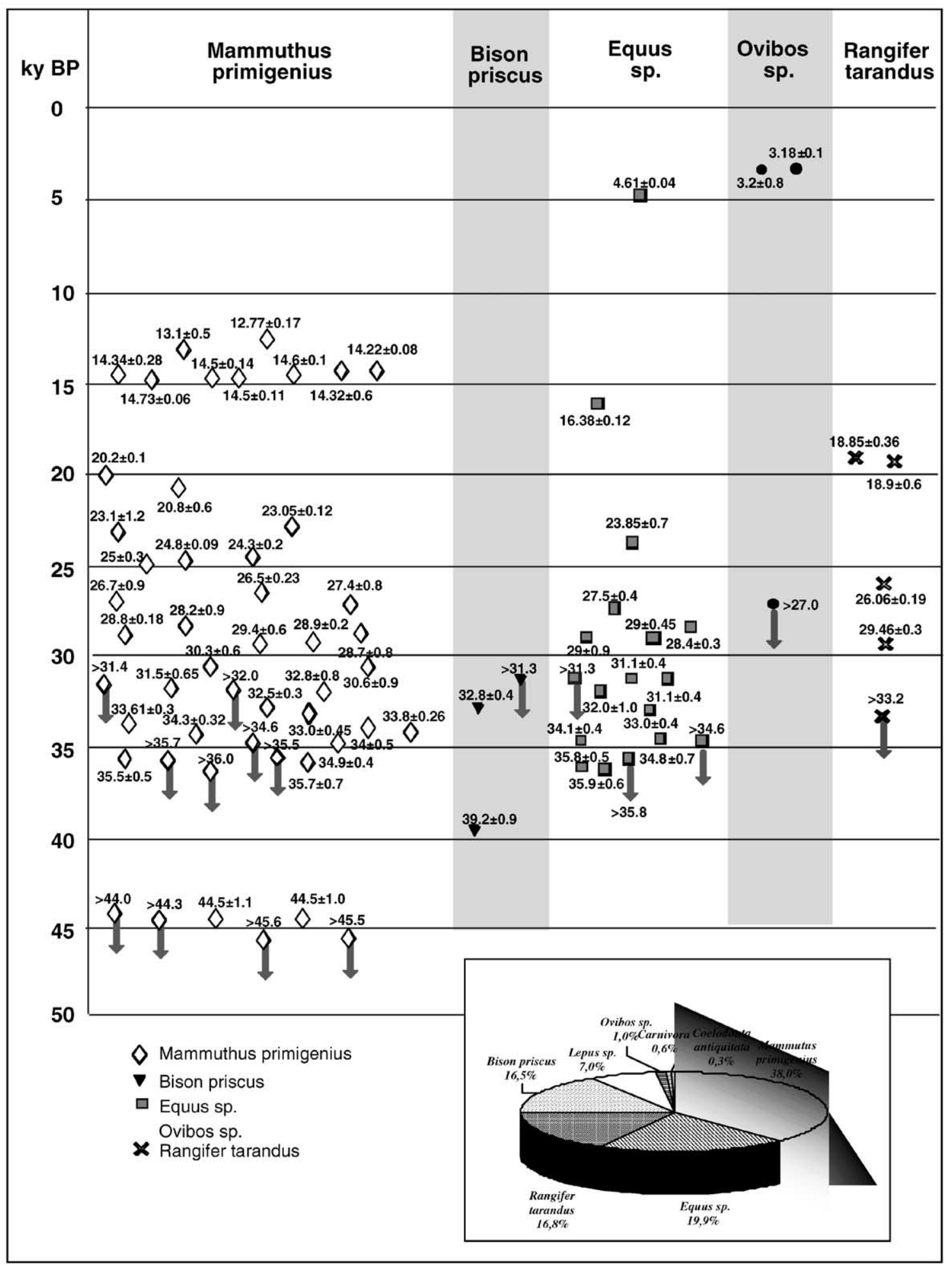

Fig. 9. Age distribution and species composition of the mammal bones collection from Bykovsky Peninsula, (total number: 1016 defined bones).

could depend also on taphonomical conditions, but we did not note such regularity. From 36 to $12.7 \mathrm{kyr}$ BP the heterogeneous bone distribution probably reflects that different numbers of animals lived in this region. The lack of mammoth dates in the period 20-14.7 kyr BP in the Bykovsky collection does not indicate the total absence of mammoths in the area, as there are dated records in adjacent areas and those farther north, but it 
reflects a relative decrease in their numbers, and probably less favorable environmental condition for mammoth life (Kuznetsova et al., 2001).

A large part of the collection consists of woolly mammoth (nearly 40\%), and mammoth dates in our database are predominant. There are also dates of large grazing mammals from which we obtained unexpected data. Two bones of muskox were dated $3,200 \pm 80$ and $3,180 \pm 100 \mathrm{yr}$ BP. These data show that in Holocene Ovibos sp. lived over more extended territory (from Yamal to Bykovsky Peninsula) than assumed before. In spite of a low quantity of horse dates (17), there is one very important age $-4610 \pm 40 \mathrm{yr}$ BP. It is one of the three Holocene dates from Equus caballus from the Arctic Region. This data proves that wild horses lived during the second part of the Holocene in the coastal land of the Arctic Ocean.

\subsection{Insects}

Thirty-seven large samples and fourteen small samples (also used for paleocarpological studies) were studied for fossil insects (Kuzmina et al., 1999; Schirrmeister et al., 1999; Sher et al., 2001; Kuzmina et al., 2001). The preservation of the insect remains generally is very good, and remains of beetles dominate. A single sample from unit A collected near sea level (radiocarbon age ca. 60-50 kyr BP) contains a few insect remains. They mostly belong to tundra species with a few remains of the typical Pleistocene tundra-steppe species.

In units B-D, insect remains are more abundant and diverse. They belong to:

(1) tundra species, living now in this area (Pterostichus (Cryobius), P. costatus, Cholevinus sibiricus, Tachinus arcticus, Chrysolina septentrionalis, Curtonotus alpinus);

(2) tundra species, also living now in different regions of Northern Yakutia, but absent on Bykovsky Peninsula (Poecilus nearcticus, Pterostichus abnormis, P. montanus, P. sublaevis, Mesotrichapion wrangelianum, Hemitrichapion tschernovi, Sitona borealis, Hypera ornata, Isochnus arcticus);

(3) steppe, meadow-steppe, and different species, living now in relict steppe areas of central Yakutia, steppelike xerophytic habitats on the Chukotka Peninsula and Wrangel Island (Stephanocleonus eruditus, Coniocleonus ferrugineus, Chrysolina arctica, Morychus viridis).

The percentage of the steppe group reaches $50 \%$ in some samples from the middle part of the section. Many remains belong to the dung beetle Aphodius (probably, one of the extinct species). These dung beetles disappeared at the end of Pleistocene together with big mammals. There are also willow weevils (Lepyrus nordenskjoeldi) and few water and riparian species.

Many species found here do not have common distribution areas today. Especially interesting is the combination of the weevils Stephanocleonus eruditus and Isochnus arcticus. The latter live now on the Wrangel Islands, Chukotka, Taymyr Peninsula and in northern Alaska, but Stephanocleonus eruditus, a true steppe species, live today in the relict steppe areas of Yakutia (where the average July temperature is $13-15^{\circ} \mathrm{C}$ ). We suppose the existence of a tundra-steppe environment. The climate was more continental with warmer summers than today and cold winters at about $48-45 \mathrm{kyr}$ BP (Table 2).

Higher in the section the insect assemblages are characterized by the absence of thermophile species. The steppe insects are also present in the sediments radiocarbon-dated to about 39-37 kyr BP, but they play a less important role. The tundra xerophilous insects are dominant together with tundra mesophilous species. The presence of the typical Arctic tundra species is also notable. During that time predominantly dry tundra, with some steppe elements, existed on Bykovsky Peninsula. There are many cold-resistant species: for example, rove beetles (Tachinus arcticus) became codominant in the mesic tundra group instead of ground beetles (Pterostichus subgenus Cryobius). We assume that the climate was rather cold.

Some thermophilic species (e.g. Pterostichus magus and Dytiscus sp.) appear in the sediments radiocarbondated at about $33 \mathrm{kyrBP}$ (upper part of unit B). Typically, these species are not currently found in tundra regions. That probably reflects a milder climate.

In the upper part of the section (unit C) strong changes of the enthomofauna are visible. The insects of the typical Arctic tundra (the weevil Isochnus arcticus) and several species of Arctic leaf beetles (Chrysolina subsulcata and Ch. tolli)) dominate in the sediments radiocarbon-dated between 24 and $18 \mathrm{kyr} \mathrm{BP}$. There are also tundra mesic and tundra xeric species, but the insects of the steppe group are almost absent (it is not excluded that single fossils are redeposited). Generally, the species diversity is very poor. These strong changes reflect a severe climate: very cold summers and winters with low moisture. These climate conditions are probably quite similar to modern ones in the northern part of Wrangel Island.

In sediments radiocarbon-dated to $17-14 \mathrm{kyr} \mathrm{BP}$ (upper part of unit C) the steppe insects again dominate. Approximately $14 \mathrm{kyr} \mathrm{BP}$, the proportion of steppe species is the highest throughout the section. During this time the special type of landscape so-called "sedge heaths" (xerophilous Carex argunensis and Politrichum piliferum dominated associations) habitats with the pill beetles (Morychus viridis) were widespread. Steppe 
fragments, similar to the relict steppe in the Yana and in the Indigirka headwaters, also existed.

The Holocene (8-9 kyr BP) insect fauna consists of tundra, taiga, water and riparian species, typical for shrub tundra and taiga (Kuznetsova et al., 1999). The climate was warmer than recently.

\section{Stable isotopes of ice wedges}

For paleotemperature reconstruction and the identification of moisture sources, stable water isotopes are widely used in paleoclimate studies. Ice wedges, as strictly periglacial features, are excellent objects for paleoclimatic research in non-glaciated areas of Northern Siberia. Oxygen and hydrogen isotopes of ice wedges are indicators for winter temperature changes. The source of ice wedge ice formation is mainly snowmelt water, which enters frost cracks formed in winter (Mackay, 1974), where it freezes rapidly enough to prevent fractionation (Michel, 1982). The stable isotope composition of ice wedges was correlated with mean annual winter and January temperatures (Vasil'chuk, 1992; Nikolayev and Mikhalev, 1995). Samples taken near the boundary of ice wedge-ice-rich sediment were discarded for paleoclimatic interpretation, because of moisture exchange between ice wedges and adjacent segregated ice in the sediment (Meyer et al., 2001a).

The results are presented in $\delta^{18} \mathrm{O} / \delta \mathrm{D}$ diagrams (Fig. 10) with respect to the Global Meteoric Water Line (GMWL), in which fresh surface waters are correlated on a global scale (Craig, 1961). In general, the most negative $\delta^{18} \mathrm{O}$ and $\delta \mathrm{D}$ values reflect the coldest temperatures. Slope and intercept in the $\delta^{18} \mathrm{O} / \delta \mathrm{D}$ diagram are valuable indicators for the identification of (1) precipitation deriving from the oceans and (2) participation of evaporation. The $d$ excess introduced by Dansgaard (1964) is an indicator for non-equilibrium fractionation processes.

The differences in mean $\delta^{18} \mathrm{O}$ and $\delta \mathrm{D}$ of Ice Complex, alas and log ice wedges represent the development of mean winter temperatures throughout time (Figs. 11
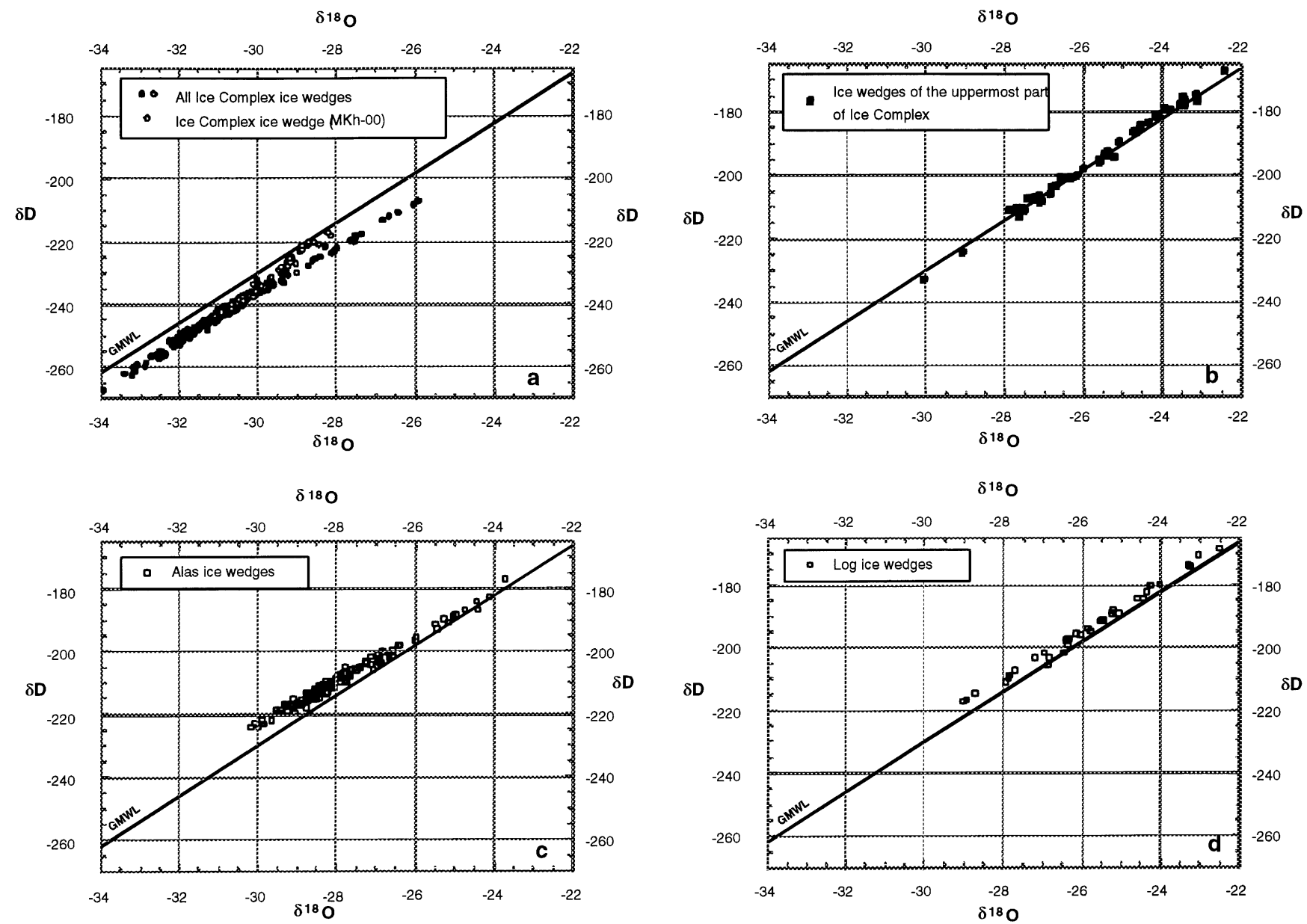

Fig. 10. Stable isotope composition of ice wedges in different permafrost deposits of the section "Mamontovy Khayata", Bykovsky Peninsula. (a) Ice Complex ice wedges (unit A-C, 60-12 kyr BP). (b) Ice wedges of the Holocene cover (unit D, about 9-7 kyr BP). (c) Ice wedges of in a filled thermokarst depression (alas) (unit E, 3-1 kyr BP). (d) Ice wedges located in deposits of a thermoerosional valley (log) (unit F, 4-1 kyr BP). 


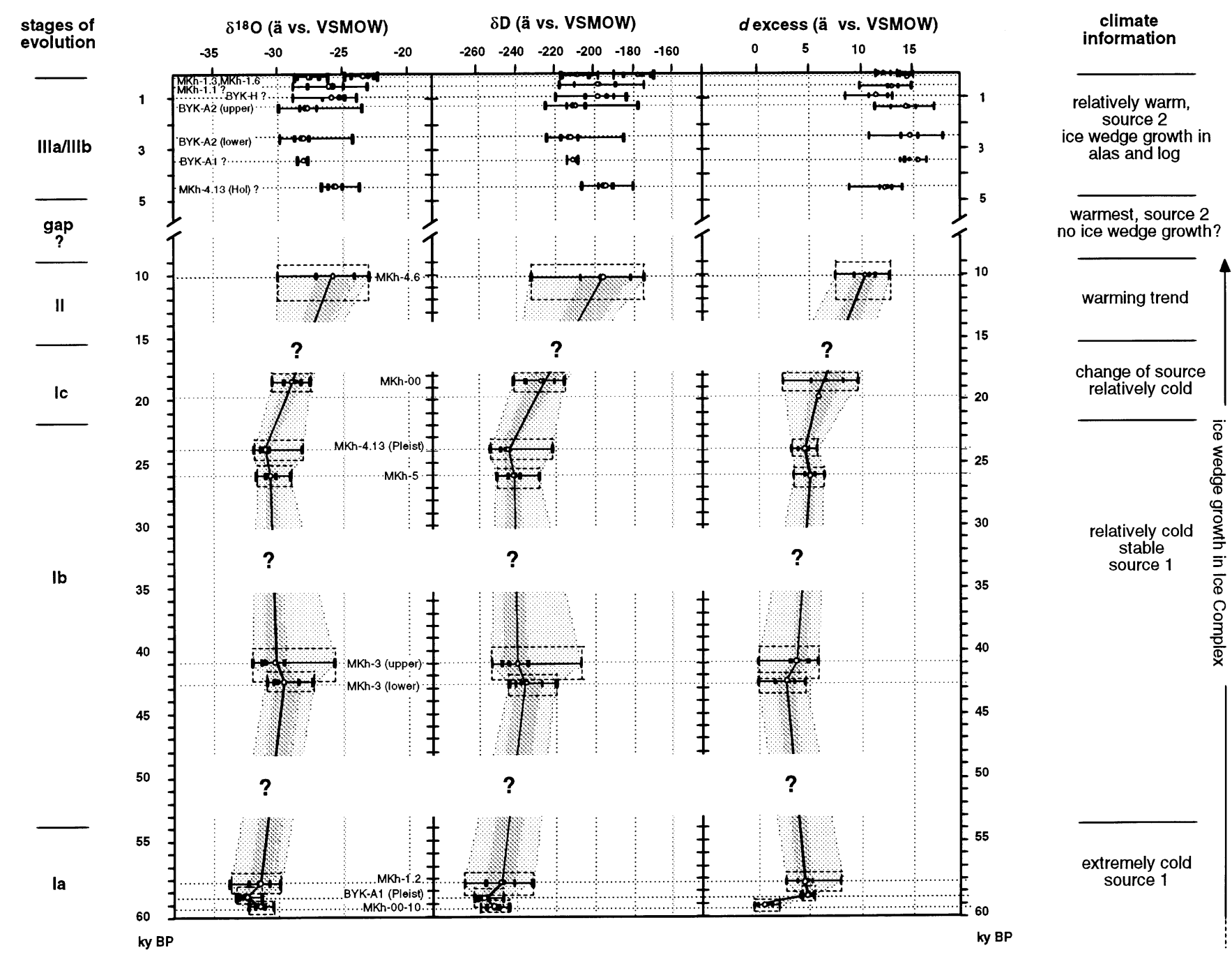

Fig. 11. Variation of stable isotope values of different Late Quaternary ice wedges from the section "Mamontovy Khayata", Bykovsky Peninsula.

and 12). Mean winter temperatures during Late Pleistocene Ice Complex formation can be assumed as consistently relatively cold (Fig. 11). The Ice Complex was subdivided into three sub-units. The coldest period was between 60 and $55 \mathrm{kyr}$ BP as indicated by low stable isotope values in ice wedges, followed by a slight rise of winter temperatures. The following period between about 45 and $22 \mathrm{kyr} \mathrm{BP}$ is characterized by very stable and cold winter conditions with low $\delta^{18} \mathrm{O}, \delta \mathrm{D}$ and $d$ excess. The heaviest $\delta^{18} \mathrm{O}$ and $\delta \mathrm{D}$ values for Ice Complex ice wedges of up to $-25 \%$ and $-190 \%$ are observed for a $42 \mathrm{kyr}$ BP old wedge at about $10 \mathrm{~m}$ a.s.l. (MKh-3). In parts, this could be attributed to exchange processes between ice wedge and segregated ice, or to less severe winter temperatures. After $22 \mathrm{kyr} \mathrm{BP}$, still relatively cold in winter, a rise in $d$ excess is observed in Ice Complex ice wedges proceeding to the Holocene. This reflects non-equilibrium fractionation caused by changing conditions, i.e. in the source of precipitation.
The Late Pleistocene cold period is apparently not seen in the stable isotopic composition of ice wedges. This may be due to missing samples for that time slice, and winters may not have been colder. A strong rise in mean $\delta^{18} \mathrm{O}$ of $5 \%$ and in $\delta \mathrm{D}$ of $25 \%$ is observed for the Pleistocene-Holocene transition and interpreted as a climate warming trend. A gap in ice wedge growth is found between about 8 and $4.5 \mathrm{kyr}$ BP. Limited or missing ice wedge growth during that time is presumably caused by the occurrence of extensive lakes. Despite insecure age estimates for Holocene ice wedges, alas ice wedges reflect slightly colder winters than $\log$ ice wedges. After $4.5 \mathrm{kyr} \mathrm{BP}$, climate deterioration and drying up of lakes is known from Taymyr Peninsula, Northern Siberia (Siegert et al., 1999), which may have caused initial ice wedge growth.

The $d$ excess of ice wedges contains information on the moisture source region for winter precipitation. The change in $d$ excess at about $20 \mathrm{kyr} \mathrm{BP}$ (Fig. 11) is 
Combination and comparison of paleoenvironmental and paleo-ecological interpretation of the multidisciplinary results

\begin{tabular}{|c|c|c|c|c|c|c|c|c|}
\hline \multirow{4}{*}{$\begin{array}{l}\text { Methods } \\
\text { Geocryology }\end{array}$} & \multicolumn{8}{|l|}{ Results and interpretations } \\
\hline & Stage 1 (50-60 kyr BP) & \multicolumn{3}{|c|}{ Stage 2 (50-25 kyr BP) } & \multicolumn{2}{|l|}{ Stage 3 (25-12 kyr BP) } & \multicolumn{2}{|c|}{ Stage $4(<12$ kyr BP $)$} \\
\hline & \multirow{2}{*}{\multicolumn{6}{|c|}{ Continuous formation of large ice wedges, Belt-like cryogenic structure, high ice content }} & \multirow{2}{*}{\multicolumn{2}{|c|}{$\begin{array}{l}\text { About } 9 \text { kyr: Thermokarst } \\
\text { processes, low ice content } \\
\text { Degradation of permafrost }\end{array}$}} \\
\hline & \multicolumn{5}{|c|}{ No fundamental change in permafrost conditions } & & & \\
\hline Sedimentology & \multicolumn{6}{|c|}{ Continuous accumulation of poorly sandy silt to silty sand without any interruption } & \multirow{2}{*}{\multicolumn{2}{|c|}{$\begin{array}{l}\text { Fine, middle and coarse } \\
\text { sand, partly with current } \\
\text { marks, discordances, } \\
\text { cryoturbations }\end{array}$}} \\
\hline & $\begin{array}{l}\text { Graded bedding, high } \\
\text { values of magnetic } \\
\text { susceptibility, weak } \\
\text { formation of cryosols }\end{array}$ & \multicolumn{3}{|c|}{ Alternation of silt and silty sand, frequent cryoturbated peaty cryosols } & \multicolumn{2}{|c|}{ Badly sorted silty sand, weak formation of cryosols } & & \\
\hline & Shallow fluvial & \multicolumn{3}{|c|}{ Variation of proluvial runoff and surface stabilization } & Local redeposition in the polyg & tundra & \multicolumn{2}{|c|}{$\begin{array}{l}\text { Destruction of former Ice } \\
\text { Complex deposits; slope an } \\
\text { lacustrine accumulation }\end{array}$} \\
\hline Mineralogy & \multicolumn{8}{|c|}{$\begin{array}{l}\text { Slight variation of clastic mineral content; high content of rock fragments (shale, shale stone, sandstone), composition similar to Quaternary deposits of the Kharaulakh Mountains } \\
\text { Uniform sources of clastic material in the neighborhood }\end{array}$} \\
\hline \multirow[t]{2}{*}{ Geo-biochemistry } & $\begin{array}{l}\text { Low TOC, low } \mathrm{C} / \mathrm{N} \text {, } \\
\text { heavy }{ }^{13} \mathrm{C} \text {-values }\end{array}$ & \multicolumn{3}{|c|}{$\begin{array}{ll}\text { Increasing of TOC, and } & \text { Large variation of TOC, } \\
\text { low } \mathrm{C} / \mathrm{N} \text { values } & \mathrm{C} / \mathrm{N} \text { and }{ }^{13} \mathrm{C} \text { values }\end{array}$} & \multicolumn{2}{|c|}{$\begin{array}{l}\text { Slight differences, low } \\
\mathrm{C} / \mathrm{N} \text { relations, heaviest }{ }^{13} \mathrm{C} \text {-values }\end{array}$} & \multicolumn{2}{|c|}{$\begin{array}{l}\text { Large variation of TOC, } \\
\text { C/N-values, light } \\
\delta^{13} \mathrm{C} \text {-values }\end{array}$} \\
\hline & $\begin{array}{l}\text { Stable surface conditions, } \\
\text { slight pedogenesis }\end{array}$ & \multicolumn{3}{|c|}{ Unstable surface conditions strong pedogensis } & \multicolumn{2}{|c|}{ Stable surface conditions, slight pedogenesis } & \multicolumn{2}{|c|}{$\begin{array}{l}\text { Unstable surface conditions } \\
\text { strong pedogenesis }\end{array}$} \\
\hline \multirow[t]{2}{*}{ Pollen } & $\begin{array}{l}\text { High content of reworked } \\
\text { Pre-Quaternary pollen, } \\
\text { scarce grass and sedge } \\
\text { vegetation, green algae, } \\
\text { shallow water }\end{array}$ & $\begin{array}{l}48-42.5 \mathrm{kyr} \\
\text { High content } \\
\text { of reworked } \\
\text { pollen, scarce } \\
\text { vegetation, } \\
\text { cover, steppe } \\
\text { and shrubby } \\
\text { tundra }\end{array}$ & $\begin{array}{l}42.5-33.5 \text { kyr Open tundra and } \\
\text { steppe-like, denser vegetation, } \\
\text { higher taxa diversity, low } \\
\text { content of redeposited pollen }\end{array}$ & $\begin{array}{l}\text { Ca. } 28.5 \text { kyr } \\
\text { Scarcer vegeta- } \\
\text { tion, open } \\
\text { tundra, } \\
\text { disturbed } \\
\text { soils }\end{array}$ & $\begin{array}{l}25.6-16 \mathrm{kyr} \\
\text { High content of reworked } \\
\text { Pre-Quaternary pollen, } \\
\text { scarce steppe-like, green } \\
\text { algae, shallow water }\end{array}$ & $\begin{array}{l}15-12 \mathrm{kyr} \\
\text { Denser vegeta- } \\
\text { tion, decrease of } \\
\text { reworked pollen } \\
\text { and green algae, } \\
\text { slight increase } \\
\text { of herbs }\end{array}$ & $\begin{array}{l}8.2-4.5 \mathrm{kyr}- \\
\text { High content } \\
\text { of tree pollen, } \\
\text { shrubby } \\
\text { tundra or } \\
\text { forest tundra }\end{array}$ & $\begin{array}{l}4.5 \mathrm{kyr}-\text { recent } \\
\text { Decrease of } \\
\text { tree pollen } \\
\text { content, } \\
\text { Arctic tundra }\end{array}$ \\
\hline & Cold and dry summers & Dry and relati & arm summers & $\begin{array}{l}\text { Dry and relative } \\
\text { cold summer }\end{array}$ & Extreme cold and dry summer & $\begin{array}{l}\text { Climate } \\
\text { amelioration }\end{array}$ & $\begin{array}{l}\text { Warmest } \\
\text { and wettest } \\
\text { summer } \\
\text { conditions }\end{array}$ & $\begin{array}{l}\text { Climate } \\
\text { change to } \\
\text { recent } \\
\text { conditions }\end{array}$ \\
\hline \multirow[t]{2}{*}{$\begin{array}{l}\text { Plant } \\
\text { macrofossils }\end{array}$} & $\begin{array}{l}58-53 \mathrm{kyr} \\
\text { Kryoxerophytic pioneer } \\
\text { plants, scarce plant } \\
\text { cover, periodical flooded } \\
\text { areas }\end{array}$ & \multicolumn{3}{|c|}{$\begin{array}{l}48-33 \mathrm{kyr} \\
\text { Kryoxerophytic pioneer, tundra bog, and water } \\
\text { plants, mosaic-like distribution of } \\
\text { extreme dry until submerse sites }\end{array}$} & \multicolumn{2}{|c|}{$\begin{array}{l}28-15 \mathrm{kyr} \\
\text { Highest rate of xerophytic plants, scarce plant } \\
\text { cover, halophytes, rare water plants }\end{array}$} & \multirow{2}{*}{\multicolumn{2}{|c|}{$\begin{array}{l}7.8-2.9 \mathrm{kyr} \\
\text { Tundra bog and nival } \\
\text { meadow plants; Early } \\
\text { Holocene increase and } \\
\text { Late Holocene decrease } \\
\text { of summer temperatures } \\
\text { Cool and moist conditions }\end{array}$}} \\
\hline & $\begin{array}{l}\text { Very cold and dry climatic } \\
\text { conditions }\end{array}$ & \multicolumn{3}{|c|}{$\begin{array}{l}\text { Unstable but strong continental climatic conditions, summers warmer than } \\
\text { today and relative moist }\end{array}$} & \multicolumn{2}{|c|}{$\begin{array}{l}\text { Stronger pronounced continentality, highest summer } \\
\text { temperatures and dry }\end{array}$} & & \\
\hline
\end{tabular}




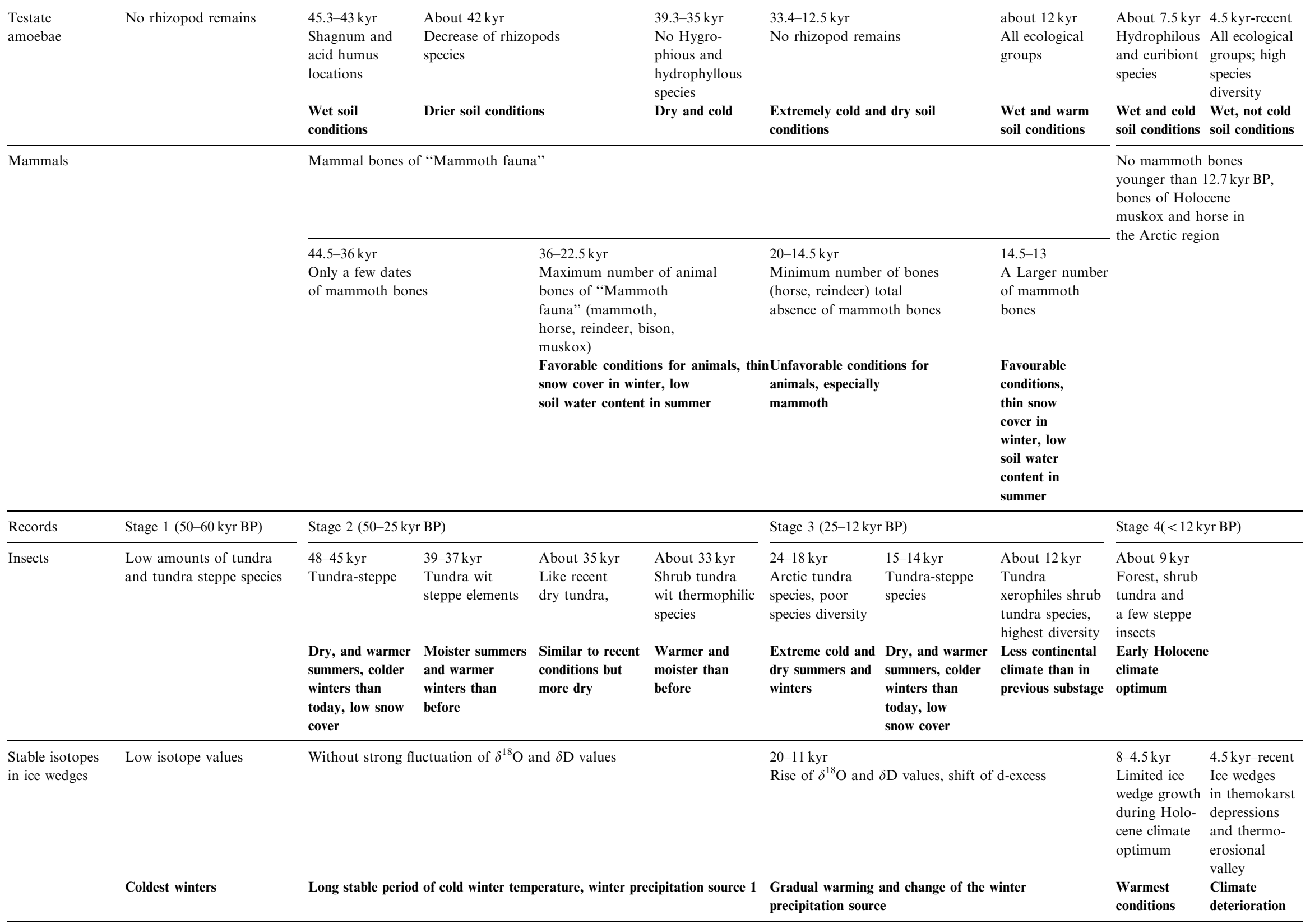


interpreted as a change in the atmospheric circulation pattern. The existence of a large Eurasian ice sheet acting as orographic barrier combined with a southward displacement of the sea ice boundary, caused moisture originating at lower latitudes of the Atlantic. Despite the larger distance to the study area, colder sea surface temperatures and higher humidity in the source region may explain the low $d$ excess in winter precipitation. In the Pleistocene, the North Atlantic moisture source region was most probably located further south.

The results obtained by studies on the Ice Complex allowed the reconstruction of the climate history and subdivision into a period of very cold winters (60$55 \mathrm{kyr} \mathrm{BP}$ ), followed by a long stable period of cold winter temperatures (50-24 kyr BP). Between $20 \mathrm{kyr}$ and $11 \mathrm{kyr} \mathrm{BP}$, climate warming is indicated by a rise in $\delta^{18} \mathrm{O}$ (of $5 \%$ ) and $\delta \mathrm{D}$ (of $25 \%$ ), most probably after the Late Glacial Maximum. A shift in the $d$ excess (of 5\%) at that time points to a change of the marine source of the precipitation from a more humid to the present North Atlantic source region.

\section{Combination of results and conclusions}

Using data from multidisciplinary studies, we try to illustrate the environmental conditions and their changes during the Late Pleistocene and Holocene. In general, according to biogeochemical data as well as bioindicator results, the permafrost sequence could be subdivided into four stages. However, some of the stages could be subdivided into several substages. An overview of the records and their interpretation is given in Table 2.

The first stage (about $60-50 \mathrm{kyr} \mathrm{BP}$ ) is characterized by dry and cold summer conditions with low bioproductivity. Very low winter temperatures are indicated by stable isotope values of ice wedges. Fluvial processes dominated the sediment accumulation. This time corresponds with the end of the Zyryanian (early Weichselian) Stadial as well as with the end of the Marine Isotope Stage (MIS) 4.

The second stage (about 50-25 kyr BP) reflects rather favorable living conditions with high bioproductivity. The summers seem to have been warmer than today but also drier. However, cold winter temperatures are inferred during this time from the stable isotope composition of ice wedges. The environment was more variable than before and after. This time interval corresponds more or less to the Kargin (middle Weichselian) Interstadial and the MIS 3.

As indicated by the character of grain size distribution, different transport processes (fluvial, eolian, nival, slopewash) seem to have participated in the accumulation of sedimentary material. Peaty soils were formed and partially cryoturbated, and peat beds accumulated during this period. As inferred from microfaunal (rhizopodes) studies the soil temperature was significantly higher than in the modern tundra. Pollen data reflect a slight warming under dry conditions at about 48-42 kyr BP indicated by steppe and shrubby tundra communities. This assumption is also supported by stable isotope values of ice wedges (Fig. 11). Relatively warm but dry conditions with a denser vegetation can be inferred between 42 and $33 \mathrm{kyr}$ BP. Results of plant macro fossil studies suggest a mosaic-like distribution of extreme dry to submersed habitats during this time. Species of tundra-steppe biomes coexisted with typical tundra marsh and tundra water plants. Warmer summer temperatures are inferred from the presence of some thermophilous hydrophytes, which today only grow in more southern areas. Similar to the pollen data, results of plant macro fossil studies divide this stage into two warmer substages, interrupted by a short cooling period. Likewise, beetle associations reflect a warmer climate with hot and dry summers for the period belonging to the first half of MIS 3 (48-35 kyr BP). In the second half of MIS 3 (35-25 kyr BP), the insects clearly mark the trend to cooler summers (Sher et al., 2001). A large number of radiocarbon dates on collagen of mammal bones collected on the Bykovsky Peninsula, show that since $45 \mathrm{kyr} \mathrm{BP}$ the woolly mammoth and since $40 \mathrm{kyr}$ BP the horse were permanent occupants. In addition, bison, reindeer and muskox occurred during this period. The number of fossil mammoth and horse remains was highest between 35 and $25 \mathrm{kyr} \mathrm{BP}$.

Relatively stable extremely cold and dry conditions and low bioproductivity characterize the third stage (about 25-12 kyr BP). This period corresponds to the Sartanian (late Weichselian) Stadial and MIS 2. Different processes similar to the previous time interval formed the sediments of the Ice Complex during this stage. Soil formation was slow (low TOC content, few rhizopod remains). The LGM is characterized by less biological activity. This is indicated by sparser vegetation cover and lower pollen productivity. Altogether, summer temperatures higher than those of today are inferred from the occurrence of plant species growing now in more southern areas. The beetle associations indicate an extreme cold continental climate during the first substage the lowest summer temperature during the LGM itself (24-18 kyr BP) and the environment probably similar to Wrangel Island. After that time, the fossil insect assemblages point to a far more continental climate with much warmer summers (Sher et al., 2001). The decrease of mammoth fossils dated to $20 \mathrm{kyr}-15 \mathrm{kyr}$ BP and their subsequent increase indicates less favorable environmental conditions for large animals during the first substage, and better conditions during the second (Kuznetsova et al., 2001).

A strong change in environmental conditions is indicated in all records of the post LGM period between 
15 and $12 \mathrm{kyr}$ BP. Stable isotope data of ice wedges point to a changing source area for precipitation probably already between 20 and $11 \mathrm{kyr}$ BP. In many records the short period of climate amelioration during the BøllingAllerød Interstadial at about $12 \mathrm{kyr} B \mathrm{P}$ is evident. Processes of thermal erosion and thermokarst have started. Fluvial transport of clastic material was activated, and peaty soil formation occurred. Denser vegetation and higher pollen productivity are inferred from pollen data. Plant species associations also indicate more favorable climate conditions.

The last stage corresponds with the Holocene or MIS 1. The degradation of permafrost by thermokarst processes and the formation of new landscapes with a great number of thermokarst lakes are typical for the early Holocene climate amelioration until about $8 \mathrm{kyr}$ BP. Additionally, gradual deterioration is visible in many paleoenvironmental records since about $4.5 \mathrm{kyr}$ BP.

As has been shown, the records indicate some differences in the time spans for environmental variations of the considered stages, and not all the records reflect always the same trends. A possible explanation is the spatial inhomogeneity of several groups of organisms. On the one hand, there are fixed and slightly movable organisms such as testate amoebae or ostracods. On the other hand, there are organisms that could move over long distances looking for food, such as large mammals. Additionally, the capability for settlement and distribution of pollen and seeds is varied. Various groups of organisms react differently to certain ecological factors. The regeneration times of different organisms, which are between some hours to decades, are of great importance. Therefore, short-living creatures indicate short-time ecological variations, and accordingly long-living organisms indicate the contrary. Additionally, the differing preservation of fossils, and the accumulation rate of sediments have to be considered. Nevertheless, the results of multidisciplinary studies present in all cases more comprehensive and more detailed environmental information than individual studies. The combination and comparison of different results makes it possible to reconstruct the variations of the whole ecosystem and not only single components.

Analysis indicates that the climatic development during the middle Weichselian (MIS 3) was marked in the North Siberian Arctic by changes of relative short warming and cooling events similar to those in western Europe (Zagwijn, 1989). However, climate fluctuations during the Late Pleistocene were revealed primarily by changing biomes, while severe geocryological conditions have remained more or less constant in the study area. As shown by the environmental interpretations of summers (mainly by bioindicators) and winters (mainly by stable isotopes of ice wedges) the climate fluctuations here suggest alterations of continentality. Stadials seem to be characterized by the highest continentality while interstadials were expressed by decreases.

A Somewhat different interpretation of the Bykovsky records, based mostly on the evidence of fossil insects and mammals, emphasizes the retention of high continentality during the whole period of 50-12 kyr BP, with variations in summer temperature (Sher et al., 2001). It also shows that summer conditions, which were warmer and much drier than today and more favorable for steppe insects, plants, and grazing mammals, were quite similar during the first half of MIS 3 (50-25 kyr BP) and the second half of MIS 2 (18-12.5 kyr BP). The second half of MIS 3 was marked by a gradual decrease in summer temperature, which reached its lowest point during the LGM (25-18 kyr BP). This concept of the last glacial environment in the study area, illustrated by the left column of Fig. 12, awaits further testing.

Located in the foreland of the Kharaulakh Mountains, the sediment accumulation was determined mainly by seasonal runoff of periglacial river systems. In addition, other processes - eolian, nival, soil erosion - have influenced sediment formation. The near-surface position of the permafrost table is associated with cryogenic polygonal relief, ice wedge polygons, intensive syngenetic ground ice accumulation, and specific pedogenesis throughout the time. Climate fluctuations have caused changes in these processes.

For the first time, continuous data sets are available from a well-dated Ice Complex sequence formed without any significant interruption during $60-10 \mathrm{kyr} B P$ for climate and environment reconstruction of the nonglaciated areas of Northeast Siberia. That is, our results argue against the "ice sheet hypothesis" proposed by Grosswald (1998) and confirm the conception of Velichko and other Russian investigators (Velichko, 1993), negating the existence of a large ice sheet in this region. The combined use of various sedimentological, geocryological, isotope, geochemical and paleontological proxies for this purpose provides new knowledge on the unique landscapes, which must have existed in the North Siberian Arctic during the last glacial period and during the transition to the Holocene. Siberian permafrost sequences are the terrestrial Arctic completion of long-term marine, lacustrine and glacial records. The interpretation of paleoenvironmental archives of permafrost sequences from the Laptev Sea region fits very well into the global Late Quaternary history. Such permafrost sequences will be used as environmental archives in the future.

\section{Acknowledgements}

The paper is based on activities, expeditions and analyses, which were mainly supported by the German Ministry of Science in the frame of the German-Russian 

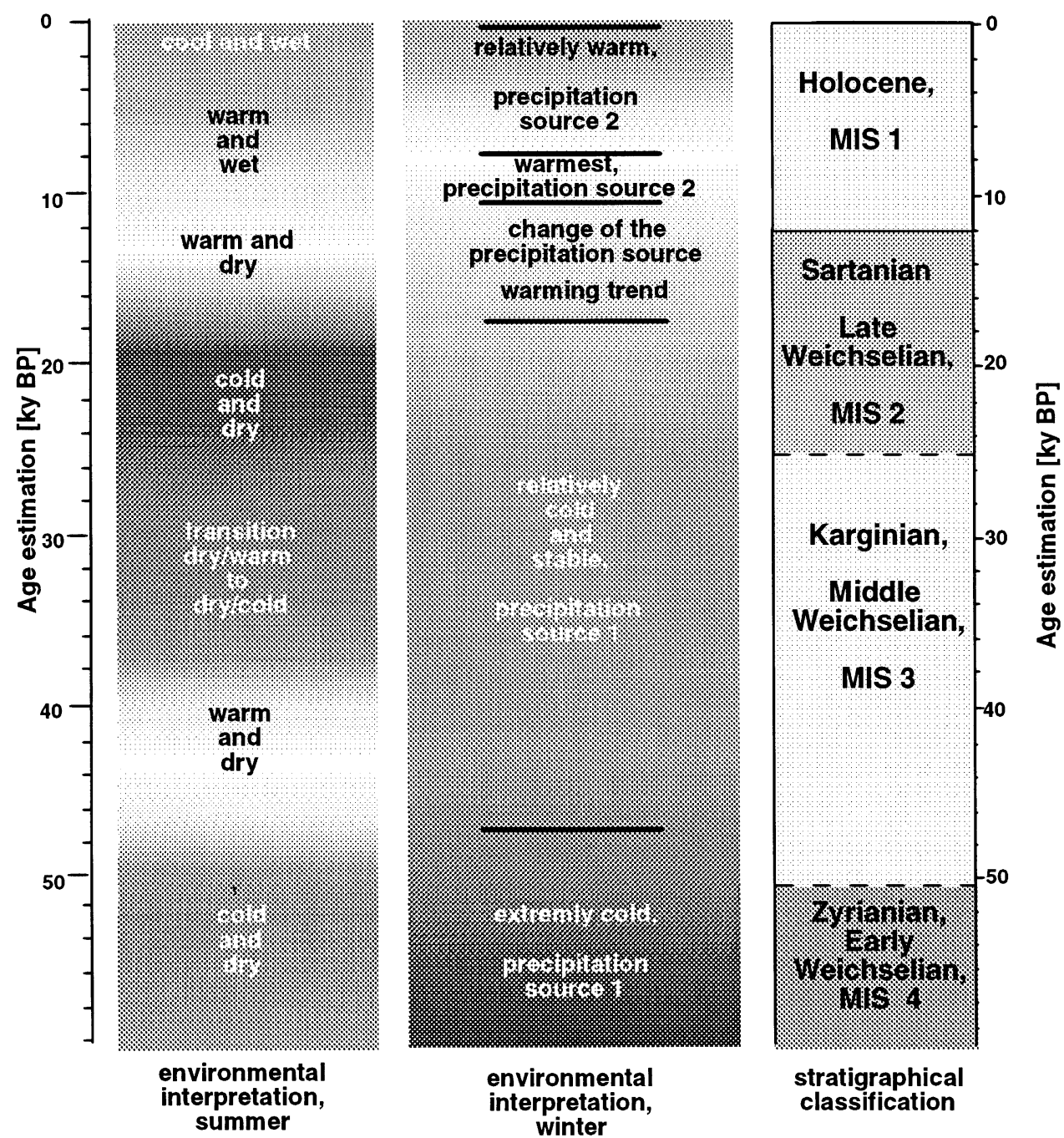

Fig. 12. General interpretation of paleoclimate and stratigraphy.

cooperation "System Laptev Sea 2000". The authors thank A. Sher for making available the profiles sampled in 1999 as well as for his promotion of young Russian scientists. Furthermore, we thank L. Sulerzhitsky for numerous bone dates, and the Leibniz-Labor in Kiel for age determination and isotope studies as well as for AMS and conventional radiocarbon dating. These results would have been never obtained without the help of the Russian colleagues A. Derevyagin, V. Tumskoy, V. Kunitsky, I. Syromyatnikov during field work. For very exact sample preparation and the great number of chemical analyses, we thank the laboratory team of the Alfred Wegener Institute in Potsdam.

\section{References}

Adams, M., 1807. Some account of a journey to the frozen sea, and of the discovery of the remains of a mammoth. Philosophical Magazine 29, 141-143.
Anderson, P.M., Lozhkin, A.V., 2001. The stage 3 interstadial complex (Karginskii/middle Wisconsinian interval) of Beringia: variations in paleoenvironmental and implications for paleoclimatic interpretations. Quaternary Science Reviews 20, 93-125.

Andreev, A.A., Klimanov, V.A., Siegert, C., Derevyagin, A. Yu., Shilova, G.N., Melles, M., 2001a. Late Pleistocene and Holocene vegetation and climate changes in the Taymyr lowland, Northern Siberia reconstructed from pollen records. Quaternary Research (accepted).

Andreev, A.A., Schirrmeister, L., Siegert, Ch., Bobrov, A.A., Demske, D., Seiffert, M., Hubberten, H.-W., 2001b. Paleoenvironmental changes in Northeastern Siberia during the Late Pleistocene-evidence from pollen records of the Bykovsky Peninsula. Polarforschung (in press).

Bobrov, A.A., Charman, D.J., Warner, B.G., 1999. Ecology of testate amoebae (Protozoa: Rhizopoda) on peatlands in western Russia with special attention to niche separation in closely related taxa. Protist 150, 125-136.

Craig, H., 1961. Isotopic variations in meteoric waters. Science 133, $1702-1703$

Dansgaard, W., 1964. Stable isotopes in precipitation. Tellus 16, 436-468. 
French, H.M., 1996. The Periglacial Environment, 2nd edition. Longman, Harlow, pp. 1-341.

Galabala, R.O., 1997. Pereletki and the initiation of glaciation in Siberia. Quaternary International 41/42, 27-32.

Gravis, G.F., 1969. Slope Deposits in Yakutia. Nauka, Moscow, pp. $1-128$.

Grigoryev, M.N., 1993. Cryomorphogenesis of the Lena Delta mouth area. Permafrost Institute, Academy of Science USSR, Siberian Department, Yakutsk, pp. 1-176 (in Russian).

Grosswald, M.G., 1998. Late-Weichselian ice sheets in Arctic and Pacific Siberia. Quaternary International 45/46, 3-18.

Hulten, E., Fries, M., 1986. Atlas of North European Vascular Plants, North of the Tropic of Cancer. Koeltz, Königstein.

Isaeva, L.L., 1984. Late Pleistocene glaciation of north central Siberia. In: Velichko, A.A., Wright, H., Barnosky, K.W. (Eds.), Late Quaternary Environments of the Soviet Union. University of Minnesota, Minneapolis, pp. 21-30.

Kaplina, T.N., Giterman, R.E., 1983. Molotkovskiy Kamen'-a key section of the second half of the Late Pleistocene on Kolyma Lowland. Izvestiya Akademii Nauk, seriya Geologicheskaya 6, 79-83 (in Russian).

Kaplina, T.N., Giterman, R.E., Lachtina, O.V., Abrashov, V.A., Kiselev, S.V., Sher, A.V., 1978. Duvannyi Yar-a key section of the upper Pleistocene sediments on Kolyma Lowland. Bulletin of Quaternary Research Commission 48, 49-65 (in Russian).

Katasonov, E.M., 1975. Frozen ground and facial analysis of Pleistocene deposits and Paleogeography of central Yakutia. Biuletyn peryglacjalny 24, 33-41.

Kienast, F., Siegert, C., Dereviagin, A., Mai, H.S., 2001. Climatic implications of late Quaternary plant macrofossil assemblages from the Taymyr Peninsula, Siberia. Global and Planetary Change (in press).

Kind, N.V., 1974. Geokhronologia pozdnego antropogena po izotopnym dannym (Geochronology of the Late Anthropogene by isotope data). Nauka, Moscow (in Russian).

Kind, N.N., Kolpakov, V.V., Sulerzhitsky, L.D., 1971. On the age of the glaciations in the Verkhonyansk Highlands. Publications of the Academy of Sciences USSR, Geology Series 10, 135-144 (in Russian).

Kunitsky, V.V., 1989. Cryolithogenesis of the Lower Lena. Permafrost Institute Academy of Science USSR, Siberian Department, Yakutsk, pp. 1-162 (in Russian).

Kuzmina, S., Kuznetsova, T., Sulershitsky, L., Sher, A., 1999. The Late Pleistocene Fauna of the Laptev Sea grassland: insects and mammals. Fifth workshop on Russian-German cooperation: Laptev Sea system, St. Petersburg, 25-29 November 1999. Terra Nostra 99/11, 48-49.

Kuzmina, S.A., Siegert, C., Sher, A.V., 2001. Fossil insects as the indicators of Quaternary environment of the Laptev Shelf land. European Union of Geologists XI Conference, Strasbourg, 8-12 April 2001, Abstracts, p. 215.

Kuznetsova, T.V., Kuzmina, S.A., Kunitsky, V.V., Schirrmeister, L., Sher, A.V., 1999. The fauna of alas sequences in the Ice Complex area: the case of Mamontovy Bysagasa northwest exposure, Bykovsky Peninsula. Fifth workshop on Russian-German cooperation: Laptev Sea system, St. Petersburg, 25-29 November 1999. Terra Nostra 99/11, 49-50.

Kuznetsova, T.V., Sulershitsky, L.D., Schirrmeister, L., Siegert, C., Hubberten, H.-W., Sher, A.V., 2001. Late Quaternary Mammals of the Laptev Shelf Land and their Environment. EUG XI, Strasbourg, 8-12 April 2001, Abstract, p. 214.

Lozhkin, A.V., 1987. Paleogeography and formation of edoma sediments of the Indigirka lowland. In: Quaternary period of Northern Asia. North East Interdisciplinary Research Institute, USSR Academy of Science, Far East Branch, Magadan, pp. 135-144 (in Russian).
Mackay, J.R., 1974. Ice wedge cracks, Garry Island, Northwest Territories. Canadian Journal of Earth Sciences 11, 1366-1383.

Meyer, H., Schönicke, L., Wand, U., Hubberten, H.-W., Friedrichsen, H., 2000. Isotope studies of hydrogen and oxygen in ground ice-experiences with the equilibration technique. Isotopes in Environmental and Health Studies 36, 133-149.

Meyer, H., Siegert, Ch., Dereviagin, A., Hubberten, H.-W., 2001 a. Paleoclimatic changes in the Late Quaternary-evidences from stable isotopes of ground ice of the Bykovsky Peninsula, NE Siberia. Polarforschung (in press).

Meyer, H., Dereviagin, A.Yu., Siegert, C., Schirrmeister, L., Hubberten, H.-W., 2001b. Hydrogen and oxygen isotopes in ground ice-a valuable tool for paleoclimate studies on Big Lyakhovsky Island, North Siberia. Permafrost and Periglacial Processes (submitted).

Michel, F.A., 1982. Isotope investigations of permafrost water in northern Canada. Ph.D. Thesis, Department of Earth Sciences, University of Waterloo, Canada, pp. 1-227.

Nadeau, M.J., Schleicher, M., Grootes, P.M., Erlenkeuser, H., Gottdang, A., Mous, D.J.W., Sarnthein, J.M., Willkomm, H., 1997. The Leibniz-Labor facility at the Christian-AlbrechtUniversity, Kiel, Germany. Nuclear Instruments and Methods in Physics Research 123, 22-30.

Nadeau, M.J., Grootes, P.M., Schleicher, M., Hasselberg, P., Rieck, A., Bitterling, M., 1998. Sample throughput and data quality at the Leibniz-Labor AMS facility. Radiocarbon 40, 239-245.

Nagaoka, D., Saijo, K., Fukuda, M., 1995. Sedimental environment of the Edoma in high Arctic eastern Siberia. In: Takahasho, K., Osawa, A., Kanazawa, Y. (Eds.), Proceedings of the Third Symposium on the Joint Siberian Permafrost Studies between Japan and Russia, Sapporo, pp. 8-13.

Nikolayev, V.I., Mikhalev, D., 1995. An oxygen-isotope paleothermometer from ice in Siberian permafrost. Quaternary Research 43, $14-21$.

Pisaric, M.F.J., MacDonald, G.M., Velichko, A.A., Cwynar, L.C., 2001. The Lateglacial and Postglacial vegetation history of the northwestern limit of Beringia, based on pollen, stomata and tree stump evidences. Quaternary Science Reviews 20, 235-245.

Romanovsky, N.N., 1993. Fundamentals of the Cryogenesis of the Lithosphere. University Press, Moscow, pp. 1-336 (in Russian).

Rozenbaum, G.E., 1981. Special features of lithogenesis of the alluvial planes in the Eastern Subarctic as related to the problem of the Ice (Yedoma) Complex. In: Popov, A.I. (Ed.), Problems of Cryolithology, Vol. 9. University Press, Moscow, pp. 87-100 (in Russian).

Schirrmeister, L., Siegert, C., Kunitsky, V.V., Meyer, H., Derevyagin, A.Yu., Kuznetsova, T.V., Kuzmina, S.A., Tumskoy, V.E., Kienast, F., Sher, A.V., 1999. Paleoenviromental and paleoclimatic records from permafrost deposits of the Bykovsky Peninsula. Fifth workshop on Russian-German cooperation "Laptev Sea System 2000", program and abstracts. Terra Nostra 99/11, 72-73.

Schirrmeister, L., Siegert, Ch., Kunitsky, V.V., Sher, A., Grootes, P., Erlenkeuser, H., 2001. Late Quaternary ice-rich permafrost sequences as an archive for the Laptev Sea Region paleoenvironment. International Journal of Earth Sciences (DOI 10.1007/ s005310100205).

Schwamborn, G., Rachold, V., Grigoriev, M.N., Andreev, A.A., Tumskoy, V., 2001a. Evolution of Lake Nikolay area, Arga Island, Western Lena River delta. Polarforschung (in press).

Schwamborn, G., Andreev, A.A., Rachold, V., Hubberten, H.-W., Grigoriev, M.N., Tumskoy, V., Pavlova, E.,Yu., Dorozkhina, M.V., 2001b. Late Quaternary sedimentation history of the Lena Delta. Quaternary International, this volume.

Sher, A.V., Kaplina, T.N., Ovander, M.G., 1987. Unified Regional Stratigraphic Chart for the Quaternary deposits in the Yana-Kolyma Lowland and its mountainous surroundings. Explanatory Note. In: Decisions of Interdepartmental Stratigraphic 
Conference on the Quaternary of the Eastern USSR. Magadan, 1982. USSR Academy of Sciences, Far-Eastern Branch, NorthEastern Complex Research Institute, Magadan, USSR, pp. 29-69 (in Russian).

Sher, A., Parmuzin, I., Bortsov, A., 2000. Ice Complex on the Bykovsky Peninsula. In: Rachold, V., Grigoriev, M.N. (Eds.), Russian-German Cooperation System Laptev Sea 2000: the Expedition LENA 1999. Reports on Polar Research, AlfredWegener-Institute for Polar and Marine Research, Bremerhaven, Vol. 354. pp. 169-182.

Sher, A.V., Kuzmina, S.A., Kuznetsova, T.V., Sulerzhitsky, L.D., Schirrmeister, L., Siegert, C., Andreev, A.A., Grootes, P., Kienast, F., Hubberten, H.-W., 2001. The last glacial environment in the unglacial Arctic Shelf Land-new evidence from the Laptev Sea coast. EUG XI, Strasbourg, 8-12 April 2001, Abstract, p. 207.

Siegert, C., Derevyagin, A.Yu., Shilova, G.N., Hermichen, W.-D., Hiller, A., 1999a. Paleoclimatic indicators from permafrost sequences in the Eastern Taymyr Lowland. In: Kassens, H., Bauch, H.A., Dmitrenko, I.A., Eicken, H., Hubberten, H.-W., Melles, M., Thiede, J., Timokhov, L.A. (Eds.), Land-Ocean system in the Siberian Arctic-Dynamics and history. Springer, Berlin, pp. 477-499.

Siegert, C., Schirrmeister, L., Kunitsky, V.V., Dereviagin, A., Krbetschek, M., Kusnetsova, T., Kuz'mina, S., Meyer, H., Sher, A., Tumskoy, V., 1999b. Paleoclimate signals in ice-rich permafrost. In: Rachold, V., Grigoryev, M.N. (Eds.), Russian-German Cooperation System Laptev Sea 2000: the Lena Delta 1998. Reports on Polar Research, Alfred-Wegener-Institute for Polar and Marine Research, Bremerhaven, Vol. 315, pp. 145-259.
Siegert, C., Schirrmeister, L., Babiy, O., 2001. The sedimentological, mineralogical and geochemical composition of Late Pleistocene deposits from the Ice Complex on the Bykovsky Peninsula, Northern Siberia. Polarforschung (in press).

Slagoda, E.A., 1991. Microstructure features of the deposits of Ice Complexes in Northern Yakutia (by the example of Bykov Peninsula). In: Gilichinskiy, D.A. (Ed.), Kriologiya pochv. Academy of Science USSR, Pushchino, IPFS PNTs AN SSSR, pp. 38-47 (in Russian).

Tomirdiaro, S.V., Chernenky, V.I., 1987. Cryogenic deposits of East Arctic and Sub Arctic. AN SSSR Far-East-Science Center, pp. 1-196 (in Russian).

Tomirdiaro, S.V., Arslanov, K.A., Chernenkiy, B.I., Tertychnaya, T.V., Prokhorova, T.N., 1984. New data on formation of loess-ice sequences in Northern Yakutia and ecological conditions of mammoth fauna in the Arctic during the late Pleistocene. Reports of the Academy of Sciences USSR 278, 1446-1449 (in Russian).

Vasil'chuk, Y.K., 1992. Oxygen Isotope Composition of Ground Ice-Application to Paleogeocryological Reconstruction. Moscow, Geological Faculty of Moscow State University, pp. 1-420 (in Russian).

Velichko, A.A. (Ed.), 1993. Development of landscapes and climate at the northern area of Eurasia (Razvitie landshaftov i klimata na territorii severnoi Evrazii). Nauka, Moscow, pp. 1-100 (in Russian).

Zagwijn, W.H., 1989. Vegetation and climate during warmer intervals in the Late Pleistocene of western and central Europe. Quaternary International 3/4, 57-67. 